\title{
URBANIZATION, MULTI-MORBIDITIES AND PREFERENCE FOR HEALTH CARE FACILITY: AN INSIGHT FROM RAJASTHAN, INDIA
}

\author{
Kshipra JAIN*, Perianaygam AROKIASAMY ${ }^{* *}$ \\ University of Rajasthan, Jaipur, India \\ * International Institute for Population Sciences, Mumbai, India
}

\begin{abstract}
India experiences rapid pace of urbanization with increasing elderly population and changing disease profile creating new set of health care demands. The study made a novel attempt by exploring the prevalence of morbidities, multi-morbidities along with preferred healthcare facility substantiated by its reasons among the older adults aged $50+$ living in urban Rajasthan based on a primary survey. The higher prevalence of single morbidity compared to multi-morbidity reflects the possibility of future healthcare needs. Poisson regression estimates identified the elderly belonging to the non-SC/ST/OBC group and the non-poor household in the age group of $60+$ at higher risk of multi-morbidities. The Government hospitals overall enjoy higher acceptance though the reasons vary from their efficiency to lacuna in other healthcare providers. The study suggests incorporating the factors shaping the preferences to develop a suitable healthcare centre for the elderly and the expansion of government healthcare schemes. Successful ageing can get a boost by adequately addressing their healthcare needs.
\end{abstract}

Key Words: urban, Rajasthan, older population, healthcare, morbidity.

\section{Introduction}

The world is experiencing demographic transition (leading to population ageing) and urbanization along with epidemiological transition particularly dominant in low and middle income countries (United Nations 2006, He et al. 2012). The simultaneous occurrence of such transitions has major implications for individuals, societies and nations as a whole. Currently, Asia is home to $54 \%$ of the world's older population, followed by Europe with a share of $24 \%$ (Lin et al. 2008). Further, it is projected that by $2050,82 \%$ of the older population would be residing in regions of Asia, Africa, Latin America and the Caribbean while only $16 \%$ would reside in developed regions of Europe and North America. It thus becomes more challenging for the developing economies that are getting old before being rich and they will also be sharing a major proportion of the older population. The issue gets aggravated with the pace of these transitions which is unprecedented; there is no historical evidence to assist the policymakers in deciding the course of governmental actions to ensure healthy urbanization as well as successful ageing (Bloom et al. 2010). India has witnessed almost tripling of its older population in the last four decades (Rajan 2006). Currently, we are home to the second largest older population of the world with a proportion of $8.6 \%$ in the total population (Census of India 2011); thus India has acquired the status of an ageing nation. This process of ageing would continue to be rapid whereby the percentage of the older population is projected to increase to $13 \%$ by 2030 and further to $20 \%$ by 2050 (United Nations 2006). Also, the Ministry of Social Justice \& Empowerment (2016) has revealed in its report that the number of older population aged 60 years and above would touch the mark of 198 million by 2030. In other words, India has a shorter time span to ensure healthy ageing in its rapidly urbanizing cities.

Globally, urbanization has registered a sharp increase from $30 \%$ in 1950 , while the percentage of urban population increased to $54 \%$ in 2014 which is further projected to increase to $66 \%$ by 2050, amounting to more number of people living in urban areas than in rural areas (United Nations 2015). At regional level, North America and Europe stands amongst the most 
urbanized regions with more than $70 \%$ of their population as urban while Asia and Africa remains mostly rural ( $48 \%$ and $40 \%$ urban population respectively) but estimating urbanization at an aggregate level reveals that Asia is home to $53 \%$ of the world's urban population followed by Europe (14\%); thus, the pace of urbanization will be faster in the Asian and African regions (United Nations 2015); a possible explanation can be the huge population base. It is projected that India, China and Nigeria as a whole will account for $37 \%$ of the growth between 2014 and 2050 with India adding the highest number of urban dwellers i.e. 404 million (United Nations 2015). This indicates that the nation with the largest rural population is bound to experience a rapid pace of urbanization in the years to come. The Indian census also confirms it as the decadal growth rate of urban population for the recent decades $(1991-2011)$ is positive while that of total and rural population is negative (Fig. 1). Consequently, percentage of urban population has increased from 11.4\% in 1901 to 31\% in 2011 (Census of India 1901, 2001 and 2011).

The simultaneous occurrence of urbanization and population ageing as a consequence of

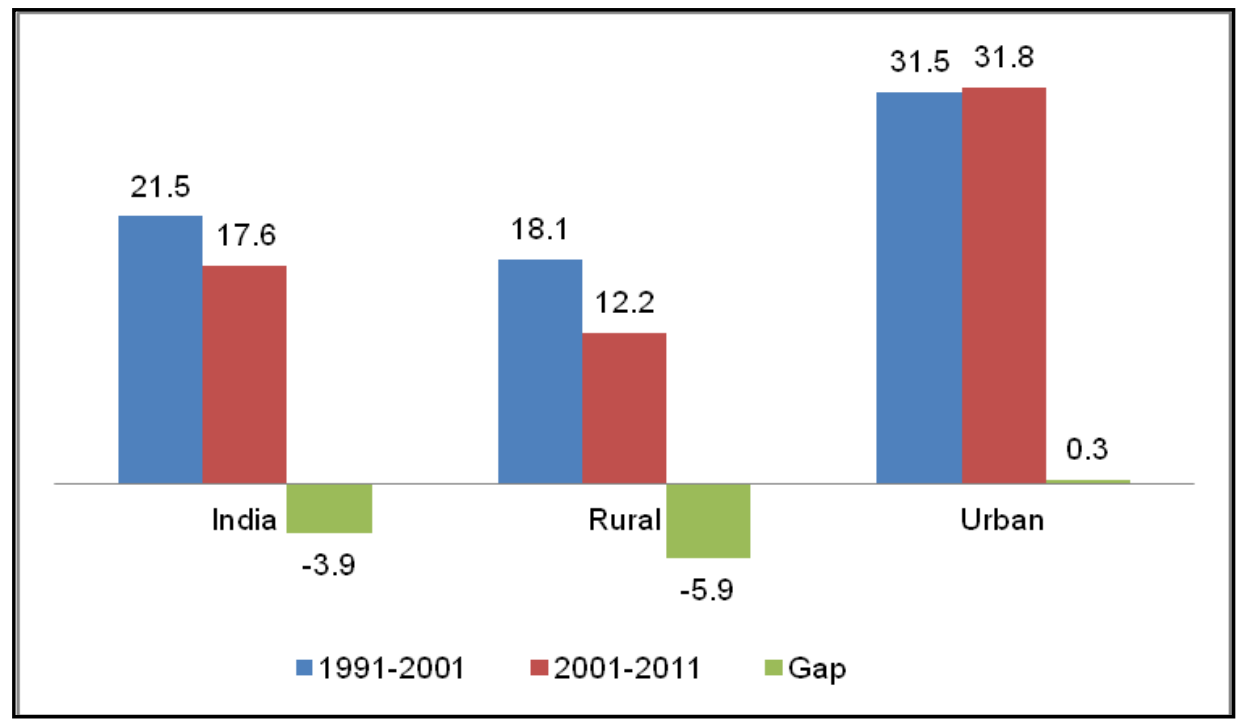

Fig. 1 - Decadal growth rate of rural, urban and total population in India Source: Census of India 2011

economic and medical science development raises various challenges particularly for the health sector since urbanization is a major determinant of public health in the 21 st century (World Health Organization 1999). It is generally believed that city dwellers enjoy a better health status (Timaeus and Lush 1995) but an increased exposure to motorized pollution, occupational physical inactivity, access to processed food, tobacco, alcohol etc. has raised critical issues related to the quality of life (Misch 1988, Allender et al. 2010, Kyobutungi et al. 2010, Wagner and Brath 2012). Indeed, mortality levels are controlled in the urban areas but the increasing prevalence of non-communicable diseases (NCDs) raises questions on adding a longer span of diseased years to the human life. The issue gets aggravated with the increasing proportion of the elderly when it is evident that the older adults are at a much higher risk for disease, disability and multiple chronic diseases (Khanam et al. 2011, Salisbury et al. 2011, Salive 2013). The World Health Organization's (2008) estimates show that NCDs accounted for $55 \%$ of deaths among the population in the age group of 15 to 60 years whereas for the older population (aged 60+) it was as high as $73 \%$. Further, more than half of the burden of NCDs and $25 \%$ of the total disease burden occur in the age group of 45 years and above (Chatterji et 
al. 2008); projected to increase to more than $45 \%$ by 2030 (Arokiasamy et al. 2015). Along with the increasing prevalence of NCDs, it is the co-existence of multiple chronic morbidities which have become progressively common among the elderly. Studies have shown that multimorbidities are not only associated with many adverse health outcomes, such as reduced physical functions (Fried et al. 1999, Kadam and Croft 2007), poor quality of life (Fortin et al. 2004), increased use of inpatient and ambulatory care (Salisbury et al. 2011), but their adverse impact is further exacerbated by socioeconomic deprivation and poor medical care facilities (Tu 2004, Lehnert et al. 2011, Marengoni et al. 2011). Another issue that seeks the attention of policymakers concerns with the availability of health care infrastructure as well as the preference of the elderly for health care facility. This was never an issue for India till recently where multiple generations staying together under one roof provided the much needed care, support and security to their elderly members (Kumar 2003, Jain and Prakash 2014); however not only India but many Asian countries are experiencing a rise in nuclear living and the diminishing preference for intergenerational co-residence (Goode 1963, Bongaarts and Zimmer 2002, Adams et al. 2011); thereby uprooting the traditional care givers. In fact, an all-together separate branch of gerontological research focused on the effects of care giving, care receipt and available care options is evolving recognizing the importance of this under researched area (Van Haitsma et al. 2013). Kane and Kane (2001) have proved that if the expectations of care are matched with the receipt of the same, it can certainly enhance the satisfaction of the elderly with care and wellbeing, particularly for the ones receiving long term care. Further, a study by Wielink et al. (1997) on the elderly living independently in the Netherlands revealed that with the extension of duration for care giving or requirement for personal care, the preference for informal care declines. Thus it becomes pertinent to assess the adequacy of health care infrastructure in accordance with the needs of the older adults.

In this background, the paper aims to assess the prevalence of multi-morbidities in a less explored setting of urban Rajasthan, India, among the population aged 50 years and above. Also, there is plenty of literature focused on various dimensions of health in the old age such as care giving framework, health care utilization and infrastructure (Mayhew 2000, Jung et al. 2003, Sheikh et al. 2015, Chokshi et al. 2016), however, studies investigating the preference of the elderly for health care facility are extremely rare. Whether older adults would prefer private doctors on government doctors or non-allopathic form of medicines such as Ayurveda, Yoga and Naturopathy, Unani, Siddha, Sowa-Rigpa and Homeopathy (AYUSH) (Rudra et al. 2017) or have no specific preference? This question becomes pertinent for the old age as the care preferences of the older may bridge the gaps between the receiver preferences and the giver decisions about the long term care planning (Reamy et al. 2011). Also, successful ageing is not only the freedom from disability but also the high cognitive, physical and social functioning (Rowe and Kahn 1987, Rowe and Kahn 1997). The paper also substantiates the preference of the elderly for health care facility by carrying out a quantitative as well as a qualitative analysis.

\section{Methodology}

\section{Selection of the Study Area}

Considering the subject matter and the objectives of the study, it was pertinent to collect primary data from Rajasthan focusing on its urban parts. With India emerging as one of the fastest growing economies, its eight states are still lagging behind i.e. Bihar, Jharkhand, Chhattisgarh, Madhya Pradesh, Rajasthan, Odisha, Uttarkhand, Uttar Pradesh grouped together as the Empowered Action Group (EAG) states to give them focused attention (Arokiasamy and Gautam 2008). Cumulatively, these states account for $46 \%$ of India's total population and $61 \%$ of the population living below the poverty line (Census of India 2011). Also, the health outcomes are worst in these states contributing to the highest disease burden in the country (Ministry of Health and Family Welfare 2011). Rajasthan, one of the EAG states, is also one of the four states selected for the pilot survey of the Longitudinal Ageing Study in 
India (LASI) focused on the population aged 45 years and above; being pioneer in such longitudinal surveys in India. LASI is a large scale, nationally representative, longitudinal survey on ageing, health and retirement with an aim of analyzing population ageing and the formulation of mid and long term policies for India (Arokiasamy et al. 2012). As per the findings of the Census of India 2011, Rajasthan is the largest state by area and the eighth largest by its population size of 68621012 people. The state is also ill famous for its poor sex ratio of 928 compared to 943 at the country level reflecting its patriarchal social structure. It is worthwhile to mention that though the sex ratio is below the national average it has improved from 921 as per the Census of India 2001. Rajasthan has a density of 200 persons per square kilometer and a literacy rate of 66.11 overall and 79.68 in the urban areas (Census of India 2011). Further, it is a state still dominated by the rural population as only one fourth of its total population resides in urban areas (17 008776 people); the study is based on the urban population of Rajasthan only.

\section{Profile of the selected District}

Rajasthan is the state with 33 districts and considering the profile of its districts, the city of Jaipur was selected as the study area. It is the capital city and commonly known as Pink City of India for its pink colored walled city. It also enjoys the status of being the first planned city of the country along with a rich cultural heritage. Apart from its historical roots, it is ranked at $10^{\text {th }}$ place in terms of the largest urban agglomeration by population size in India (Census of India 2011) as well as one of the four cities of Rajasthan selected for the Smart city mission, the Government of India recognizing its pace of modernization. The Ministry of Housing and Urban Affairs launched this mission in 2015 , aiming at the promotion of such cities that can provide core infrastructure and ensure a decent quality of life to its citizens, a clean and sustainable environment along with the application of 'Smart' Solutions (Ministry of Urban Development 2015). Further, the Ministry defines the focus of this mission on sustainable and inclusive development and creating a replicable model in compact areas to act like a light house to other aspirant cities; Jaipur being selected as one of the light house cities. Hence, it will be insightful to assess the health care needs and preferences of the older adults living in a light house city. Further, as per the Census of India $2011,20.49 \%$ of the urban population of Rajasthan, i.e. 34 099204 people, resides in urban Jaipur. The literacy rate in Jaipur district is 76.44 with 82.47 in the urban parts which is higher than the average literacy rate at the state level for overall and urban areas as well (Census of India 2011). Further, the per capita income of the city is $€$ 461.54 (Government of Rajasthan 2015). This study is focused on the population aged 50 years and above living in the urban parts of Jaipur district which constitutes $11.55 \%$ of the total urban population of Jaipur i.e. 288927 people (Census of India 2001). Since it is the work of an individual researcher and also there is hardly a study focused on Jaipur, this study therefore fulfills the research gap as well.

\section{Sampling}

The survey design of the study is finalized by following the Encyclopedia of Survey Research Methods edited by Lavrakas (2008) and other research based on primary data such as the work done by Banjare and Pradhan (2014); hence, a five stage sampling procedure was adopted to select the respondents from urban Jaipur. A brief description of the sampling design is given below:

1. The sample size ${ }^{1)}$ was calculated using the sample size formula to arrive at a sample of $400^{2)}$ older adults aged 50 years and above living in the urban parts of Jaipur:

1) This method requires a target precision for the estimates and a given design effect (with the adjustment for expected non-response) (Lwanga and Lemeshow 1991).

2) The sample size formula estimated the number of respondents at 362 , but to ensure adequate cell frequency the sample size was inflated to 400 . 


$$
n=\frac{\mathrm{Z}_{\alpha}^{2} * \mathrm{p} * \mathrm{q} *(1+\mathrm{R}) *(\text { deff })}{\mathrm{d}^{2}}
$$

where, $\mathrm{n}=$ estimated sample size

$\alpha=$ level of statistical significance that was set at 0.05

$Z_{\alpha}=$ the $z$ value at $95 \%$ confidence level i.e. $z_{\alpha}=1.96$, with $95 \%$ confidence level

$d=$ the margin of error i.e. $d=0.05$

$p=$ the proportion of older adults aged 50 years and above i.e. $\mathbf{p}=\mathbf{0 . 1 2}$

$q=1-p$ i.e. $q=0.89$

$\mathrm{R}=$ non-response rate i.e. $\mathbf{R}=\mathbf{0 . 1 0}$

deff $=$ design effect i.e. deff $=2$

2. In the second stage, it was purposively decided to collect data from five urban wards out of 91 wards divided into eight zones of Jaipur Municipal Corporation ${ }^{3)}$. The wards were selected on the basis of their residential pattern so as to capture different socioeconomic segments of the population to the largest possible extent. It is however important to note that there is no official record stating the residential pattern and it is based on the observation of the researcher as well as on the findings from the pilot survey ${ }^{4}$. Hence, the information about the five selected wards is given in Table 1 .

3. In the third stage, from each of the five wards, one census enumeration block (CEB) was randomly selected.

4. In the fourth stage, the operation of housing list was carried out in each of the selected CEB of five wards. The minimum eligibility criterion for listing the household was the presence of at least one person in the age group of 50 years and above in the household.

5. In the fifth stage, following the systematic random sampling, households were selected from each of the five CEBs using the household list. It implies that every fifth household listed on the household list was selected for the interview to ensure systematic randomness while selecting the sample.

Information of selected wards (Urban Jaipur, 2012)

Table 1

\begin{tabular}{|l|c|c|l|l|}
\hline $\begin{array}{l}\text { Ward } \\
\text { Number }\end{array}$ & $\begin{array}{c}\text { No of } \\
\text { Households }\end{array}$ & $\begin{array}{c}\text { Total } \\
\text { population }\end{array}$ & $\begin{array}{c}\text { Selected } \\
\text { Area }\end{array}$ & \multicolumn{1}{|c|}{$\begin{array}{c}\text { Major Population } \\
\text { Characteristic }\end{array}$} \\
\hline Ward No 17 & 224 & 1415 & Bani Park & Richer section \\
\hline Ward No 27 & 9177 & 41058 & $\begin{array}{l}\text { Mansorover } \\
\text { (SFS colony) }\end{array}$ & Retired government officials \\
\hline Ward No 35 & 11895 & 58027 & Jhalana & Lower income group \\
\hline Ward No 38 & 6320 & 29333 & $\begin{array}{l}\text { Malviya } \\
\text { Nagar }\end{array}$ & $\begin{array}{l}\text { Business and teacher com- } \\
\text { munity }\end{array}$ \\
\hline Ward No 54 & 6919 & 34534 & Ramganj & Muslim population \\
\hline
\end{tabular}

Source: Directorate of Census Operation, Jaipur office; Jain and Arokiasamy 2016

3) See Appendix 1 for the ward map.

4) During the in-depth interviews at the time of the pilot survey, the elderly were asked about the residential pattern of the city. 


\section{Health care assessment}

Since the study is based on primary data ${ }^{5}$, a cross-sectional survey design consisting two sets of self-administered questionnaire, i.e. Household questionnaire and Individual questionnaire, were developed ${ }^{6}$. The former is used to collect information about the household and its members (such as ownership of household assets which is used to calculate the wealth index using the Principal component analysis), while the latter is used to collect specific information about the respondents (such as age, gender, education status, caste, religion). The data on the prevalence of various morbidities was collected by asking the elderly the following specific question: "If any health professional has ever diagnosed them with a (particular) chronic disease or minor ailment in the last one year or last 30 days preceding the survey respectively."

The responses were recorded without conducting any clinical or cross examination of medical reports. Further, consistent with the research carried out in the field of multi-morbidity (for example, Khanam et al. 2011, Arokiasamy et al. 2015), the study defined it as the simultaneous presence of two or more chronic conditions at the time of the survey based on the information collected on individual chronic diseases ${ }^{7}$. Further, in order to meet the second objective about the health care preferences, the elderly were asked the following questions according to the ailment: "Which health facility do you prefer for health care and treatment seeking in case of any minor ailment? Which health facility do you prefer for health care and treatment seeking in case of any major illness?". The rationale for asking two separate questions was to rule out the probability of having different preferences for a different nature of disease. The reasons that shaped the preferences of the elderly for health care facility were also explored.

\section{Data Processing}

The field work for data collection from the 400 elderly aged $50+$ was carried out in urban Jaipur during August 2012 to January 2013. The data so collected was then entered using the United States Census Bureau's Census and the Survey Processing System (CSPro) version 4.0.1 which is being widely used for processing of survey data. The data was entered as two separate files, i.e. Household file and individual file, which were later on merged with assigned unique identification codes and converted into STATA version 10 (Stata Corporation, College Station, Texas, USA) for the purpose of the analysis. It is important to note that the necessary editing and cleaning of data was undertaken before carrying out the analysis.

\section{Statistical tool}

Considering the objectives of the study, the uni-variate, bi-variate and multi-variate analyses were carried out ${ }^{8)}$. The bi-variate associations are tested using the chi-squared goodness of fit statistics which is used as a test for counts and to determine how well each item contributed to a common dependent variable (Phaswana-Mafuya et al. 2013). In the multi-variate analysis, the Poisson regression model is applied as the prevalence of multi-morbidity turned out to be a rare event. Also, its use is justified based on the statistically significant value of the Wald chisquare statistic for the full model ( $p$-value for the chi square) (Saikia and Ram 2010). A brief description of the model is as follows:

5) In primary data, information is collected and used for the first time by the investigator/ researcher.

6) See Appendix 2 and 3. diseases.

7) The information collected is used to estimate the prevalence of no disease, one disease and 2+

8) See Appendix 4 for the demographic and economic profile of the respondents. 
Poisson Regression Model: A Poisson random variable $\mathrm{Y}$ has the probability density function, $f(y)=P(Y=y)$ given as,

$$
f\left(Y_{i}\right)=\frac{e^{-\mu} \mu^{Y}}{Y !}
$$

where, $f(Y)$ denotes the probability that the variable $Y$ takes non-negative integer values. The parameter $\mu$ is the mean value of the random variable $Y$ which takes on values from zero to infinity, at integers.

The Poisson regression model may be written as:

$$
Y_{i}=E\left(Y_{i}\right)+u_{i}=\mu_{i}+u_{i}
$$

where the Y's are independently distributed as Poisson random variables with means $\mu_{i}$ for each individual expressed as (Gujarati 2009):

$$
E\left(Y_{i}\right)=\mu_{i}=\left\{\beta_{1}+\beta_{2} x_{2 i}+\beta_{3} x_{3 i}+\ldots+\beta_{k} x_{k i}\right\} .
$$

\section{Ethical Consideration and Informed Consent}

This study is based on primary data collected from the older population aged 50 years and above living in the urban parts of Jaipur. A due attention is paid to the ethical considerations by taking a prior approval for the study and questionnaire from the International Institute for Population Sciences, Mumbai. Respondents were interviewed only after taking their informed consent wherein they were assured of keeping their identity anonymous and information shared as confidential. Also, their participation in the survey was voluntary and they were free to discontinue the interview at any point of time and they could choose not to answer the questions they did not like.

\section{Results}

\section{Prevalence of Morbidities and Multiple morbidities}

The first objective of the study is to assess the prevalence of various morbidities among the older population, defined in terms of morbidity, multi-morbidities and zero morbidity along with individual distribution of diseases (Fig. 2). The findings reveal that $28 \%$ did not report any disease while $40 \%$ suffered from one disease and $31 \%$ reported the prevalence of multiple diseases. Considering chronic diseases, the majority of elderly reported hypertension (39\%) followed by diabetes (24\%) and arthritis (23\%). Angina and lung disorders were reported by $13 \%$ of the elderly. Further, less than $10 \%$ of the elderly suffered from heart diseases (eight percent); thyroid (four percent); spondylitis (three percent); genital ulcers (two percent); polio/ paralysis (one percent) and less than one percent complained about slip disc and cervical ${ }^{9}$. Among the minor ailments, problems related to vision were the most commonly reported $(66 \%)$ followed by fatigue (44\%), dental problems $(40 \%)$ and prolonged cough $(27 \%)$.

9) The reason for such less percentages was not the less prevalence of these diseases, but rather the elderly who were bed ridden were either unwilling for the interview or those who consented couldn't complete their interviews 


\section{Association of socioeconomic factors with the prevalence of morbidities}

This section deals with exploring the crude associations of multi-morbidities with the socioeconomic and demographic characteristics of the elderly in order to identify the vulnerable groups (Table 2). As expected, the older adults reported comparatively a better health status defined in terms of zero morbidities and multi-morbidities than the oldest old $(34 \%$ and $23 \%$ for zero morbidity and $25 \%$ and $37 \%$ for multi-morbidities for the population aged $50-59$ years and $60+$ respectively). In a patriarchal Indian society, females are often an ignored gender yet biologically stronger; hence, $33 \%$ of older males reported multi-morbidities compared to $28 \%$ of older females though the other two indicators preferred older males. Education and economic status depicts a positive association with multi-morbidities justified on the grounds of a reporting pattern shaped up by the awareness levels. Also, the percentage of older adults suffering from multi-morbidities was more among those living in non-nuclear families $(33 \%)$ and belonging to other caste group (34\%) and to the Hindu religion compared to their counter parts ( $24 \%$ for nuclear families and the deprived caste group and $27 \%$ for the Non-Hindu religion).

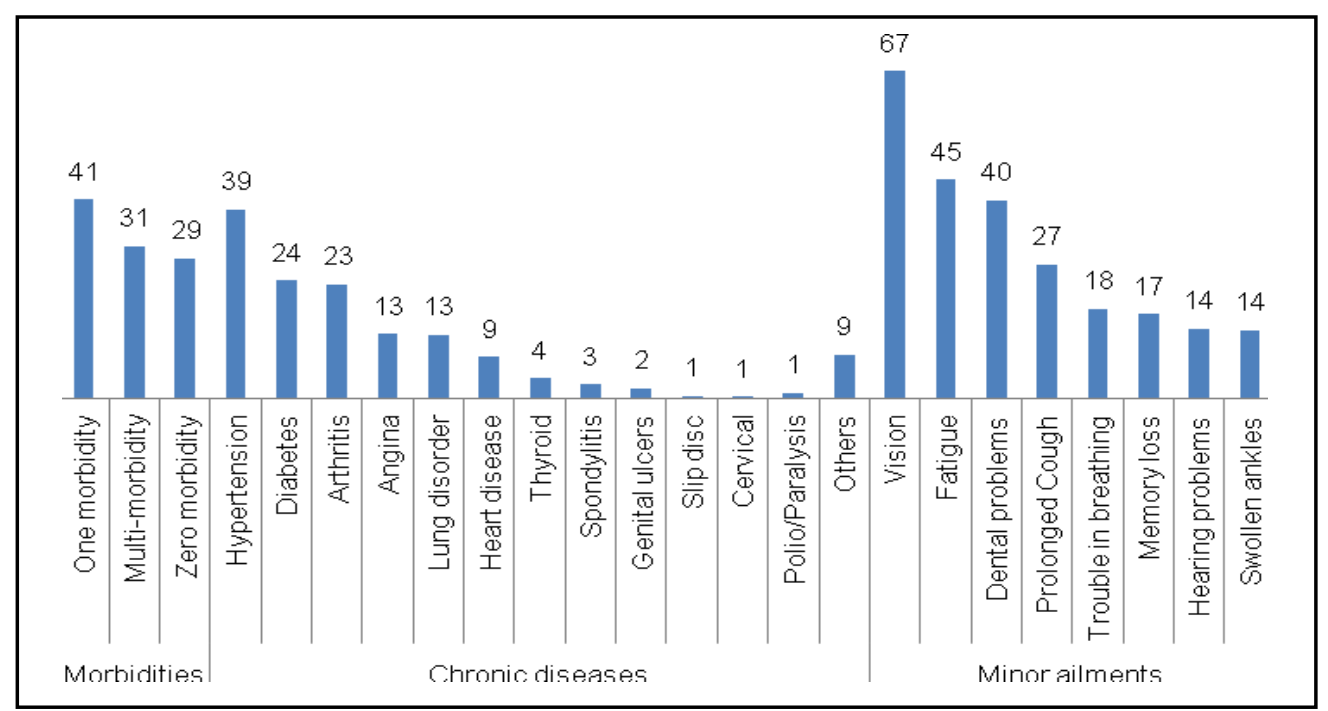

Fig. 2 - Morbid conditions among the elderly aged 50 years and above (per cent distribution by morbidities, Urban Jaipur, 2013)

Note: Percentage may add up to more than 100 because of multiple responses

\section{Socioeconomic correlates of multiple morbidities}

The crude associations were further explored using the sophisticated regression analysis. Table 3 presents the estimates from the Poisson regression model used to examine the determinants of multi-morbidities relative to the reference category "no morbidity". The results are consistent with the patterns as indicated in the bivariate analysis. For instance, among the predictors, age, caste and the economic status of the elderly are of importance. Age has significant effect on the prevalence of morbidities as older adults aged 60+ have a 1.36 times higher risk of morbidity than those in the age group of 50-59 years. The effect of caste on the risk ratio is paradoxical as the elderly belonging to the deprived caste group experienced a $26 \%$ lesser risk ratio of morbidity than their counterparts. Similarly, the elderly from the households with medium and high standard of living experienced a $28 \%$ and $27 \%$ higher risk ratio of morbidity than the elderly from the low standard of living households. 
Prevalence of multiple diseases among the elderly, by socioeconomic characteristics (Urban Jaipur, 2013)

\begin{tabular}{|c|c|c|c|}
\hline SES characteristics & Zero morbidity & One morbidity & Multi-morbidity \\
\hline \multicolumn{4}{|l|}{$\mathrm{Age}^{\star *}$} \\
\hline $50-59$ years & 34.17 & 41.21 & 24.62 \\
\hline $60+$ year & 22.89 & 39.80 & 37.31 \\
\hline \multicolumn{4}{|l|}{ Gender } \\
\hline Male & 29.55 & 37.65 & 32.79 \\
\hline Female & 26.80 & 45.10 & 28.10 \\
\hline \multicolumn{4}{|l|}{ Educational level ${ }^{*}$} \\
\hline No education & 27.27 & 47.27 & 25.45 \\
\hline Up to higher secondary & 30.10 & 41.75 & 28.16 \\
\hline Graduation & 31.16 & 41.30 & 27.54 \\
\hline $\begin{array}{l}\text { Post-graduation and } \\
\text { above }\end{array}$ & 24.04 & 34.62 & 41.35 \\
\hline \multicolumn{4}{|l|}{ Working status ${ }^{\star \star *}$} \\
\hline Currently working & 36.36 & 40.64 & 22.99 \\
\hline Retired & 22.64 & 35.85 & 41.51 \\
\hline Not working & 20.56 & 44.86 & 34.58 \\
\hline \multicolumn{4}{|l|}{ Living Arrangement } \\
\hline Nuclear & 31.33 & 44.58 & 24.10 \\
\hline Non-Nuclear & 27.76 & 39.43 & 32.81 \\
\hline \multicolumn{4}{|l|}{ Caste } \\
\hline Others & 23.91 & 42.03 & 34.06 \\
\hline $\mathrm{SC} / \mathrm{ST} / \mathrm{OBC}$ & 38.71 & 37.10 & 24.19 \\
\hline \multicolumn{4}{|l|}{ Religion* } \\
\hline Hindu & 30.40 & 36.63 & 32.97 \\
\hline Non-Hindu & 24.41 & 48.82 & 26.77 \\
\hline \multicolumn{4}{|l|}{ Wealth** } \\
\hline Poor & 34.33 & 44.78 & 20.90 \\
\hline Middle & 27.07 & 36.09 & 36.84 \\
\hline Rich & 24.06 & 40.60 & 35.34 \\
\hline Total & 28.50 & 40.50 & 31.00 \\
\hline
\end{tabular}

Notes: ${ }^{* *}$ significant at $1 \%$ level of significance $(p<0.01) ;{ }^{* *}$ significant at $5 \%$ level of significance $(p<0.05)$; *significant at $10 \%$ level of significance $(p<0.10)$, as per the Chi-squared test results.

Overall, the elderly belonging to the forward caste group (non-SC/ST/OBC) and the non-poor households in the age group of $60+$ were at a higher risk of morbidities. The results derived consistency with the literature that with poor socio-economic standing sometimes an individual's own understanding of health may not be in accordance with the appraisal of medical experts and thus they fail to realize the presence of a morbid condition and they do not report it (Sen 2002, Jain et al. 2012).

\section{Preference for health care facility}

There is a plethora of literature focused on the various dimensions of health such as health care infrastructure and their adequacy and availability (Sheikh et al. 2015, Chokshi et al. 2016); 
however, studies exploring the preference of people for health care facility are relatively rare. Since the old age needs much of health care, the knowledge about their preferences would certainly assist in designing the appropriate type of health care infrastructure. When in this

Table 3

Poisson regression results (IRR) showing the effect of socioeconomic and demographic predictors on the prevalence of multiple morbidities among the elderly aged $50+$ (Urban Jaipur, 2013)

\begin{tabular}{|c|c|c|c|}
\hline \multirow[b]{2}{*}{ Morbidity } & \multirow[b]{2}{*}{ IRR } & \multicolumn{2}{|c|}{ 95\% Confidence Interval } \\
\hline & & Lower Limit & Upper Limit \\
\hline \multicolumn{4}{|l|}{ Age } \\
\hline \multicolumn{4}{|l|}{$50-59$ Years $®$} \\
\hline $60+$ & $1.38^{* * *}$ & 1.15 & 1.65 \\
\hline \multicolumn{4}{|l|}{ Educational level } \\
\hline \multicolumn{4}{|l|}{ No education $\AA$} \\
\hline Up to secondary & 0.89 & 0.66 & 1.21 \\
\hline Graduation & 1.02 & 0.69 & 1.52 \\
\hline Post-graduation \& above & 1.26 & 0.86 & 1.87 \\
\hline \multicolumn{4}{|l|}{ Gender } \\
\hline \multicolumn{4}{|l|}{ Male® } \\
\hline Female & 0.91 & 0.77 & 1.09 \\
\hline \multicolumn{4}{|l|}{ Caste } \\
\hline \multicolumn{4}{|l|}{ Other Caste $®$} \\
\hline SC/ST/OBC & $0.74^{\star * *}$ & 0.61 & 0.92 \\
\hline \multicolumn{4}{|l|}{ Religion } \\
\hline \multicolumn{4}{|l|}{ Hindu® } \\
\hline Muslim & 1.04 & 0.79 & 1.37 \\
\hline Others & 0.95 & 0.78 & 1.16 \\
\hline \multicolumn{4}{|l|}{ Living Arrangement } \\
\hline \multicolumn{4}{|l|}{ Nuclear® } \\
\hline Non-Nuclear & 1.19 & 0.96 & 1.49 \\
\hline \multicolumn{4}{|l|}{ Economic Status } \\
\hline \multicolumn{4}{|l|}{ Poor® } \\
\hline Middle & $1.36^{* *}$ & 1.07 & 1.73 \\
\hline Rich & $1.37^{* *}$ & 1.05 & 1.78 \\
\hline Constant & 0.88 & 0.57 & 1.36 \\
\hline $\mathrm{N}$ & & 400 & \\
\hline Wald Chi-Square (13) & & 50.8 & \\
\hline Prob> Chi-Square & & 0.000 & \\
\hline Pseudo R Square & & 0.0353 & \\
\hline
\end{tabular}

Notes: ${ }^{* * *} p<0.01 ;{ }^{* *} p<0.05 ;{ }^{*} p<0.10$;

(B: reference group;

IRR: Incidence Risk Ratio.

study the older adults were asked about their preference for the type of health care facility, their response varied with the types of morbidities (Table 4). To illustrate this, $42 \%$ of them preferred the government hospitals for the treatment of chronic diseases $(42 \%)$ while for minor 
ailments, the majority preferred home remedies on any other health care facility $(31 \%)$. Despite increasing the consumption of allopathic medicines, AYUSH still managed to be a preferred option by $14 \%$ of the older adults for minor ailments. Further, $15 \%$ and three percent of the respondents did not have any specific health care preference for chronic and minor morbidities respectively.

Most preferred health care facility by type of ailment (Urban Jaipur, 2013)

\begin{tabular}{|l|c|c|}
\hline Health facility & Chronic diseases & Minor ailments \\
\hline Government Hospitals/Clinics & 42.50 & 22.50 \\
\hline Community/Charity Centers & $\#$ & 3.00 \\
\hline Private practitioners/Hospitals & 33.75 & 17.00 \\
\hline AYUSH & 0 & 14.50 \\
\hline Pharmacy/Drug Store & NA & 8.50 \\
\hline Home Remedies & NA & 31.50 \\
\hline NGO/Trust Hospitals & 7.00 & 0 \\
\hline No Specific Preference & 15.50 & 3.00 \\
\hline
\end{tabular}

Note: \# cell frequency is less than 8

While responding to the question of preference for health care facility, a few of the older adults $(31 \%)$ expressed their strong inclination for a particular health care facility irrespective of the nature of ailment (Table 5). Fourteen percent of the elderly have always preferred the government hospitals or clinics followed by $10 \%$ of the elderly with the preference for private hospitals and seven percent for NGO/Community hospitals. Sixty nine percent of the elderly did not have any specific preference and they were quite flexible with their choice of health care facility.

Percentage of the elderly with fixed preference for health care facility

Table 5 (Urban Jaipur, 2013)

\begin{tabular}{|l|c|c|}
\hline Fixed preference & Percent & N \\
\hline Government Hospitals & 14.25 & 57 \\
\hline NGO/Community/Charity Hospitals & 7.00 & 28 \\
\hline Private Hospitals & 9.75 & 39 \\
\hline Flexible preference & 69.00 & 276 \\
\hline
\end{tabular}

Factors governing the preference for health care facility

Though the elderly have revealed their preference for health care facility, it would be insightful to understand the factors responsible for shaping up such preferences in order to ascertain the strengths and weaknesses of the exiting health care infrastructure (Fig. 3). The availability of better facilities (32\%) and best doctors $(23 \%)$, as well as affordability $(23 \%)$, was amongst the most commonly reported factors. The facilities of reimbursement and CGHS hospitals also emerged as factors for seven and four percent of the elderly respectively. It is important to note that none of the older adults covered under the CGHS scheme have preferred any other health care facility except the CGHS approved health care facility; hence, there is a need to expand the social security benefits. It was also observed that the choice for a particular health care facility emerged on the account of refusal to other facility. For instance, nine percent of the 
elderly did not visit a particular health care facility owing to lack of adequate infrastructure; however, they were indifferent to any other facility. Likewise, two percent of the elderly did not visit a health care facility as they believed providers to be dishonest.

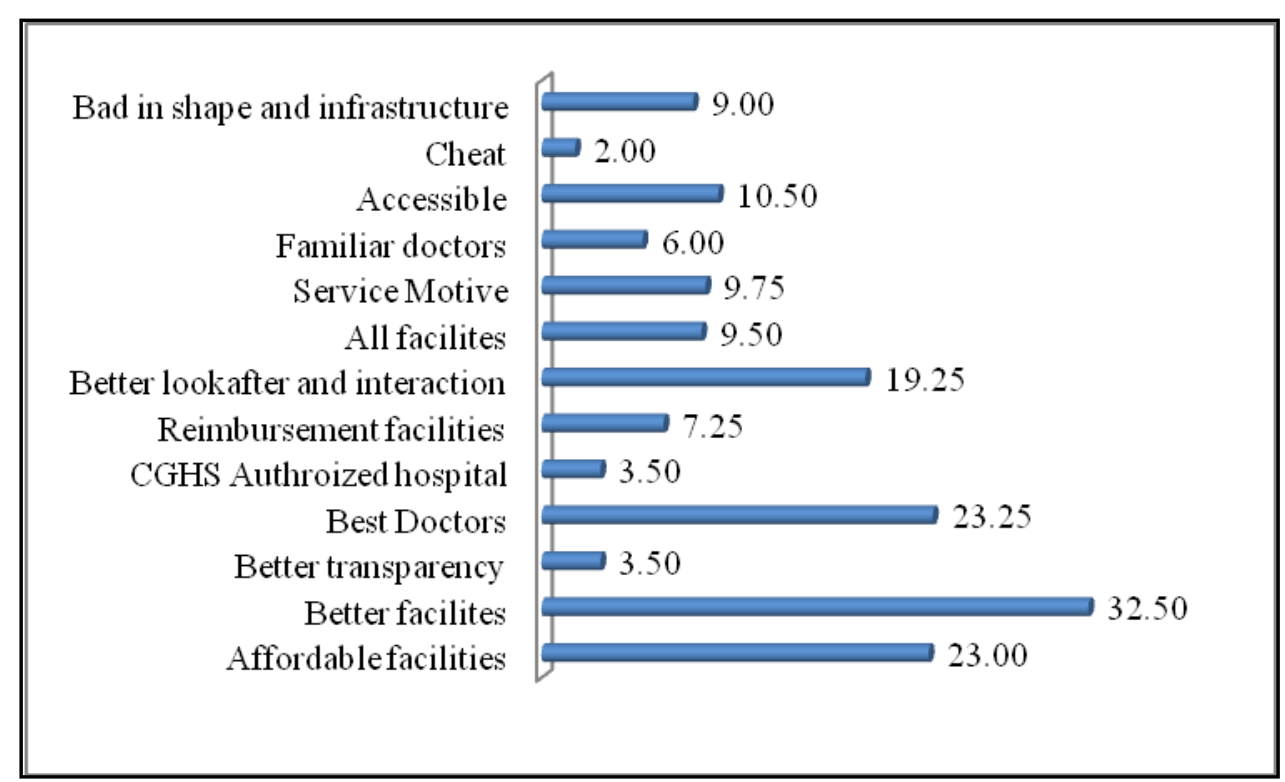

Fig. 3 - Factors governing the preference for the health care facility (Urban Jaipur, 2013)

The factors shaping up the preferences were re-analyzed by the type of health care facility to evaluate such facilities from a consumer's view point (Table 6). The majority of the elderly who preferred government facilities rationalized their choice based on the availability of best doctors $(61 \%)$ followed by the affordable facilities $(37 \%)$ and a belief that these hospitals are governed by service motive (18\%). Likewise, in the context of NGO/Charity facilities, $50 \%$ of the elderly preferred it because they believed facilities to be better while $18 \%$ chose this facility owing to its accessibility. Fifty six percent of the elderly who preferred the private health care facility were governed by the availability of better facilities and look after while $23 \%$ of them preferred it due to the lack of proper infrastructure in other health care facilities; hence, the weakness of other health care providers led older adults to prefer private providers.

The quantitative analysis has clearly brought out the factors shaping the preferences; the qualitative excerpts would however allow us to explain their rationale; for instance, a married male aged 64 years and an elderly widow aged 79 years narrated their reasons for preferring the government hospital:

"The reliability of the private hospitals is very suspicious... they are sitting there to make money... but government doctors are much more qualified and have service motive... they won't make us to go for unnecessary tests..." [Married male, 64 years].

“Doctors in government hospitals don't listen to us properly... there are such long queues and it becomes difficult for me to wait... but I have no choice... I am dependent on my kids after their uncle's death... I have to go where there are lesser fees..." [Elderly widow, 79 years]. 
These two elderly preferred government hospitals however their reasons differ considerably; for the former, good facilities are shaping the preference as well as the lack of trust on the other health facility while for the latter there is no willingness to prefer this hospital, but owing to lesser fees, she was forced to. Likewise, there were few more respondents who did not like a particular health facility and so they either chose another or they were forced to visit the same health care facility.

Table 6

Percent distribution of the elderly according to the preferred health care facility by their reasons (Urban Jaipur, 2013)

\begin{tabular}{|l|c|c|c|c|}
\hline \multirow{2}{*}{ Reasons } & \multicolumn{4}{|c|}{ Facilities } \\
\cline { 2 - 5 } & Government & NGO/Charity & Private & Not specific \\
\hline Affordable facilities & 36.84 & 28.57 & 0 & 22.83 \\
\hline Better facilities & 17.54 & 50.00 & 56.41 & 30.43 \\
\hline Better transparency & $\#$ & $\#$ & $\#$ & $\#$ \\
\hline Best Doctors & 61.40 & 10.71 & 0 & 19.93 \\
\hline Reimbursement & 12.28 & $\#$ & $\#$ & 11.23 \\
\hline $\begin{array}{l}\text { Better look after and } \\
\text { interaction }\end{array}$ & 5.26 & $\#$ & 56.41 & 17.03 \\
\hline All facilities & 17.54 & 0 & 0 & 10.14 \\
\hline Service Motive & 17.54 & 14.29 & 0 & 9.06 \\
\hline Familiar doctors & 0 & 10.71 & $\#$ & 6.52 \\
\hline Accessible & $\#$ & 17.86 & 0 & 12.68 \\
\hline Cheat & $\#$ & 0 & 0 & $\#$ \\
\hline Bad in infrastructure & 0 & 14.29 & 23.08 & 8.33 \\
\hline
\end{tabular}

Note: \# cell frequency is less than 8

\section{Discussion}

Ageing and healthy ageing are two separate issues; the former is bound to happen beyond the control of governments while the latter is to be ensured by policymakers. By now, ageing has hit most of the countries and a crossover of an increasing older population and a declining child population is projected when the number of children and older persons will be the same (United Nations 2006). Both these sub-groups are the largest consumers of health services though they need an all together different health care infrastructure. Hence, it is of utmost importance to carry out systematic studies dealing with the different dimensions of population ageing such as financial needs, wellbeing, and health care infrastructure to assist policymakers in formulating effective policies and interventions. In the context of India, there is limited literature on the socioeconomic correlates of multi-morbidities among the elderly population (Himanshu and Talukdar 2017) and this study has attempted to fill this research gap by providing insights upon Rajasthan, the largest state of India. The findings from the study reveal that multimorbidities are reported by $31 \%$ of the elderly; however the prevalence of only a single morbidity is reported among $41 \%$ of the study population which reflect the risk group for multimorbidities. Thus, the burden on health care resources appears to be increasing in the near future. The study also identified the vulnerable groups that need targeted attention. For instance, the older adults belonging to the non-SC/ST/OBC group and to non-poor households in the age group of $60+$ were at a higher risk of multi-morbidities. Though it does not entail for the immunity of their counterparts from multi-morbidities, it should rather be understood in the terms of deciding a starting point for the targeted intervention. 


\begin{abstract}
A comparison of the results with the available literature divulges into some contradictory as well as similar results. A study carried out in Chandigarh found the elderly females more prone to morbidities (Swami et al. 2002) but in Karnataka no gender differentials were observed (Shraddha et al. 2012) while this study found a lesser prevalence of multi-morbidities among the elderly females in urban Rajasthan. In addition, consistent with the findings of Banjare and Pradhan (2014), Ha et al. (2015) and Mini and Thankappan (2017), this study also revealed a higher prevalence of multi-morbidities among the well-off section of the society. Further, since India is in the early stages of establishing government programs to support its aging population (Arokiasamy et al. 2012, Jain and Arokiasamy 2016), exploring the preferences of the elderly for health care infrastructure would be insightful. This study shows an inclination towards government hospitals as $14 \%$ of the older adults have always preferred government hospitals or clinics while nearly $10 \%$ preferred the private hospitals. It is worthwhile to mention that the entire group of older adults covered under the CGHS scheme has always preferred those hospitals affiliated with the scheme; hence, there is $100 \%$ acceptance and utilization of the scheme among masses.
\end{abstract}

The study acknowledges that each country has its own pace of demographic transition and urbanization. The initiatives taken by the developed world such as the restructuring of policies, pension plans and health care infrastructure to ensure successful ageing can still be suggestive of effective policies though they should be modified and adopted according to their own needs. In fact, the state based care options prevailing in Europe differ by scope, organization and quality within the European countries. So that, in Sweden and the Netherlands, health care infrastructures are funded by the state, while Switzerland employs a local system of services and the Denmark represents the example of a public-private policy of both pensions and savings (Davey et al. 2014, Smits et al. 2014, Mair et al. 2016). Similarly, the Stockholm European Council defined a three-pronged strategy to address population ageing through: 1) reducing public debt, 2) raising employment rates and productivity, and 3) reforming pension, health care and long-term care systems (European Commission 2014), while Lee and Mason (2006) believed that European policies should now be designed to exploit the 'second demographic dividend'. India is though in the stage of reaping its first demographic dividend; however, considering the pace of transitions occurring concomitantly, the government should integrate the elements of these lessons in its ageing policies, particularly focusing on health and long term care systems.

\title{
Conclusions
}

The essence of this paper lies in assisting the government to provide for adequate health care infrastructure for the elderly by exploring the prevalence of morbidities and multi-morbidities as well as the preference of the elderly for health care facility shaped up by their reasons in an urban set up. The study recommends the government to keep in mind the preferences of the older adults while designing appropriate geriatric hospitals. Though there was an inclination towards government hospitals, in few instances, there was observed that, apart from quality, lacunas in the non-government health care providers left the older adults with this option which remains valid for choosing a different health care provider in other instances as well. Thus, the burden of government doctors should be reduced by either hiring more staff or creating more hospitals; also, there should be some stringent regulations to monitor the functioning of private providers. The recent incidence of sheer negligence by some big private providers in few cities of India calls for strict actions by the government to avoid such incidences in the future where the possibility of under reporting cannot be ignored. The insight gleaned from the study strongly suggests the expansion of coverage under the insurance schemes (such as CGHS) at least in the urban areas where these schemes have already become popular. Hence, if the inhibiting or promoting factors can be rectified or strengthened, the shape of health care infrastructure will be in accordance with the needs of the elderly. 
The study is though based on the data collected from the urban areas of the largest state of India. So that, it would be unjust to generalize the findings for the whole country, but still, the prevalence of morbidities and the preference for health care facility can assist the government in predicting future health care needs and the type of infrastructure required to cater to such needs. Also, the scenario depicted in urban areas can be indicative of the quantum of health care needs in the rural areas where under-reporting is a major issue due to widespread illiteracy and unawareness about the morbid conditions.

Finally the study concludes by an urge to alter the assumption of considering the older population as a burden on resources, and the concept of successful ageing can certainly assist us in this drive. If their health needs are adequately addressed, this sub-group of population is a rich source of experiences which none of the text books can ever teach.

\section{References}

ADAMS K. B., LEIBBRANDT S., MOON H. (2011), A critical review of the literature on social and leisure activity and wellbeing in later life, Ageing \& Society 31 (4), 683-712.

ALLENDER S., LACEY B., WEBSTER P., RAYNER M., DEEPA M., SCARBOROUGH P., ARAMBEPOLA C., DATTA M., MOHAN V. (2010), Level of urbanization and noncommunicable disease risk factors in Tamil Nadu, India, Bulletin of the World Health Organization 88 (4), 297-304.

AROKIASAMY P., BLOOM D., LEE J., FEENEY K., OZOLINS M. (2012), Longitudinal Aging Study in India: Vision, Design, Implementation and Preliminary findings, in: Smith J. P., Majmundar M. (eds.), Aging in Asia: Findings from new and emerging data initiatives, The National Academies Press, Washington, DC, pp. 36-74.

AROKIASAMY P., GAUTAM A. (2008), Neonatal mortality in the empowered action group states of India: trends and determinants, Journal of Biosocial Sciences 40 (2), 183-201.

AROKIASAMY P., UTTAMACHARYA, JAIN K. (2015), Multi-morbidity, functional limitations, and self-rated health among older adults in India: Cross-sectional Analysis of LASI Pilot Survey, 2010, SAGE Open 5 (1), 1-10.

BANJARE P., PRADHAN J. (2014), Socio-Economic Inequalities in the Prevalence of Multi-Morbidity among the Rural Elderly in Bargarh District of Odisha (India), PLOS ONE 9 (6), e97832, 1-10.

BLOOM D. E., CANNING D., FINK G. (2010), Implications of population ageing for economic growth, Oxford Review of Economic Policy 26 (4), 583-612.

BONGAARTS J., ZIMMER Z. (2002), Living arrangements of older adults in the developing world: an analysis of demographic and health survey household surveys, The Journals of Gerontology Series B: Psychological Sciences and Social Sciences 57 (3), S145S157.

CHATTERJI S., KOWAL P., MATHERS C., NAIDOO N., VERDES E., SMITH J. P., SUZMAN R. (2008), The health of aging populations in China and India, Health Affairs 27 (4), 1052-1063.

CHOKSHI M., PATIL B., KHANNA R., NEOGI S. B., SHARMA J., PAUL V. K., ZODPEY S. (2016), Health systems in India, Journal of Perinatology 36 (Suppl. 3), S9-S12.

DAVEY A., MALMBERG B., SUNDSTRÖM G. (2014), Aging in Sweden: Local variation, local control, The Gerontologist 54 (4), 525-532.

EUROPEAN COMMISSION (2014), Population Ageing in Europe: Facts, Implications and Policies, Publications Office of the European Union, Luxembourg.

FORTIN M., LAPOINTE L., HUDON C., VANASSE A., NTETU A. L., MALTAIS D. (2004), Multimorbidity and quality of life in primary care: a systematic review, Health and Quality of Life Outcomes 2, 51.

FRIED L. P., BANDEEN-ROCHE K., KASPER J. D., GURALNIK J. M. (1999), Association of comorbidity with disability in older women: The Women's Health and Aging 
Study, Journal of Clinical Epidemiology 52 (1), 27-37. GOODE W. J. (1963), World revolution and family patterns, Columbia University, New York.

GUJARATI D. N. (2009), Basic econometrics, Tata McGraw-Hill Education, New Delhi. HA N. T., LE N. H., KHANAL V., MOORIN R. (2015), Multimorbidity and its social determinants among older people in southern provinces, Vietnam, International Journal for Equity in Health 14, 50.

HE W., MUENCHRATH M. N., KOWAL P. (2012), Shades of gray: a cross-country study of health and well-being of the older populations in SAGE countries, 2007-2010, U.S. Government Printing Office, Washington, DC.

HIMANSHU, TALUKDAR B. (2017), Prevalence of multimorbidity (Chronic NCDS) and associated determinants among elderly in India, Demography India (Special Issue), 69-76.

JAIN K., AROKIASAMY P. (2016), Ageing and depression assessment: A study of urban India, JSM Anxiety and Depression 1 (4), 1020.

JAIN K., GOLI S., AROKIASAMY P. (2012), Are self-reported morbidities deceptive in measuring socio-economic inequalities, The Indian Journal of Medical Research 136 (5), 750 757.

JAIN K., PRAKASH M. (2014), Is economic security of Elderly a concern for India: A systematic review of Indian Plans and Policies, Indian Journal of Gerontology 28 (2), 244-259.

JUNG H. P., BAERVELDT C., OLESEN F., GROL R., WENSING M. (2003), Patient characteristics as predictors of primary health care preferences: a systematic literature analysis, Health Expectations 6 (2), 160-181.

KADAM U. T., CROFT P. R. (2007), Clinical multimorbidity and physical function in older adults: a record and health status linkage study in general practice, Family Practice 24 (5), 412-419

KANE R. L., KANE R. A. (2001), What older people want from long-term care, and how they can get it, Health Affairs 20 (6), 114-127.

KHANAM M. A., STREATFIELD P. K., KABIR Z. N., QIU C., CORNELIUS C., WAHLIN A. (2011), Prevalence and patterns of multimorbidity among elderly people in rural Bangladesh: a cross-sectional study, Journal of Health, Population and Nutrition 29 (4), 406-414.

KUMAR S. V. (2003), Economic security for the elderly in India: an overview, Journal of Ageing and Social Policy 15 (2-3), 45-65.

KYOBUTUNGI C., EGONDI T., EZEH A. (2010), The health and well-being of older people in Nairobi's slums, Global Health Action 3 (1), 2138.

LAVRAKAS P. J. (ed.) (2008), Encyclopedia of Survey Research Methods, SAGE Publications, London.

LEE R., MASON A. (2006), What is the demographic dividend?, Finance and Development 43 (3).

LEHNERT T., HEIDER D., LEICHT H., HEINRICH S., CORRIERI S., LUPPA M., RIEDEL-HELLER S., KÖNIG H. H. (2011), Review: Health care utilization and costs of elderly persons with multiple chronic conditions, Medical Care Research and Review 68 (4), 387-420.

LIN P. C., YEN M., FETZER S. J. (2008), Quality of life in elders living alone in Taiwan, Journal of Clinical Nursing 17 (12), 1610-1617.

LWANGA S. K., LEMESHOW S. (1991), Sample size determination in health studies: $A$ practical manual, World Health Organization, Geneva.

MAIR C. A., QUIÑONES A. R., PASHA M. A. (2016), Care Preferences among MiddleAged and Older Adults with Chronic Disease in Europe: Individual Health Care Needs and National Health Care Infrastructure, The Gerontologist 56 (4), 687-701.

MARENGONI A., ANGLEMAN S., MELIS R., MANGIALASCHE F., KARP A., GARMEN

A., MEINOW B., FRATIGLIONI L. (2011), Aging with multimorbidity: A systematic review of the literature, Ageing Research Reviews 10 (4), 430-439.

MAYHEW L. (2000), Health and elderly care expenditure in an aging world, International Institute for Applied Systems Analysis, Laxenburg. 
MINI G. K., THANKAPPAN K. R. (2017), Pattern, correlates and implications of noncommunicable disease multimorbidity among older adults in selected Indian states: a crosssectional study, BMJ Open 7 (3), e013529, 1-6.

MINISTRY OF HEALTH AND FAMILY WELFARE (2011), Family welfare statistics in India 2011, Government of India, New Delhi.

MINISTRY OF URBAN DEVELOPMENT (2015), Smart cities: Mission Statement \& Guidelines, Government of India, New Delhi.

MINISTRY OF SOCIAL JUSTICE \& EMPOWERMENT (2016), Integrated program for older persons: A central sector scheme to improve the quality of life of the older persons, Government of India, New Delhi.

MISCH K. A. (1988), Ischaemic heart disease in urbanized Papua New Guinea. An autopsy study, Cardiology 75 (1), 71-75.

PHASWANA-MAFUYA N., PELTZER K., CHIRINDA W., KOSE Z., HOOSAIN E., RAMLAGAN S., TABANE C., DAVIDS A. (2013), Self-rated health and associated factors among older South Africans: evidence from the study on global ageing and adult health, Global Health Action 6, 19880.

RAJAN S. I. (2006), Population Ageing and Health in India, Centre for Enquiry into Health and Allied Themes, Mumbai.

REAMY A. M., KIM K., ZARIT S. H., WHITLATCH C. J. (2011), Understanding discrepancy in perceptions of values: individuals with mild to moderate dementia and their family caregivers, The Gerontologist 51 (4), 473-483.

ROWE J. W., KAHN R. L. (1987), Human aging: usual and successful, Science 237 (4811), 143-149.

ROWE J. W., KAHN R. L. (1997), Successful aging, The Gerontologist 37 (4), 433-440

RUDRA S., KALRA A., KUMAR A., JOE W. (2017), Utilization of alternative systems of medicine as health care services in India: Evidence on AYUSH care from NSS 2014, PLOS ONE 12 (5), e0176916, 1-20.

SAIKIA N., RAM F. (2010), Determinants of adult mortality in India, Asian Population Studies 6 (2), 153-171.

SALISBURY C., JOHNSON L., PURDY S., VALDERAS J. M., MONTGOMERY A. A. (2011), Epidemiology and impact of multimorbidity in primary care: a retrospective cohort study, British Journal of General Practice 61 (582), e12-e21.

83.

SALIVE M. E. (2013), Multimorbidity in older adults, Epidemiologic Reviews 35 (1), 75-

SEN A. (2002), Health: perception versus observation, BMJ 324 (7342), 860-861.

SHEIKH K., SALIGRAM P. S., HORT K. (2015), What explains regulatory failure? Analysing the architecture of health care regulation in two Indian states, Health Policy Plan 30 (1), 39-55.

SHRADDHA K., PRASHANTHA B., PRAKASH B. (2012), Study on morbidity pattern among elderly in urban population of Mysore, Karnataka, India, International Journal of Medicine and Biomedical Research 1 (3), 215-223.

SMITS C. H. M., VAN DEN BELD H. K., AARTSEN M. J., SCHROOTS J. J. F. (2014), Aging in the Netherlands: State of the art and science, The Gerontologist 54 (3), 335-343.

SWAMI H. M., BHATIA V., DUTT R., BHATIA S. P. S. (2002), A community based study of the morbidity profile among the elderly in Chandigarh, India, Bahrain Medical Bulletin 24 (1), 13-16.

TIMAEUS I. M., LUSH L. (1995), Intra-urban differentials in child health, Health Transition Review 5, 163-190.

TU H. T. (2004), Rising health costs, medical debt and chronic conditions, Center for Studying Health System Change Issue Brief 88, 1-5. New York.

UNITED NATIONS (2006), World Population Prospects: 2006 revision, United Nations,

UNITED NATIONS (2015), World Urbanization Prospects: The 2014 Revision, United Nations, New York. 
VAN HAITSMA K., CURYTO K., SPECTOR A., TOWSLEY G., KLEBAN M., CARPENTER B., RUCKDESCHEL K., FELDMAN P. H., KOREN M. J. (2013), The preferences for everyday living inventory: scale development and description of psychosocial preferences responses in community-dwelling elders, The Gerontologist 53 (4), 582-595.

WAGNER K.-H. H, BRATH H. (2012), A global view on the development of non communicable diseases, Preventive Medicine 54 (Suppl.), S38-S41.

WORLD HEALTH ORGANIZATION (1999), Creating healthy cities in the 21st century, in: Satterthwaite D. (ed.), The Earthscan Reader in Sustainable Cities, Earthscan Publications, London.

WORLD HEALTH ORGANIZATION (2008), The World Health Report 2008: primary healthcare - now more than ever, World Health Organization, Geneva.

WIELINK G., HUIJSMAN R., MCDONNELL J. (1997), Preferences for care: A study of the elders living independently in the Netherlands, Research on Aging 19 (2), 174-198.

Initial submission: 10.01.2018

Revised submission: 20.05 .2018

Final acceptance: 12.11.2018

Correspondence: Department of Economics, University of Rajasthan, Rajasthan University Campus, Talvandi, Jaipur, Rajasthan 302004, India.

Email: kshipraaa@gmail.com 


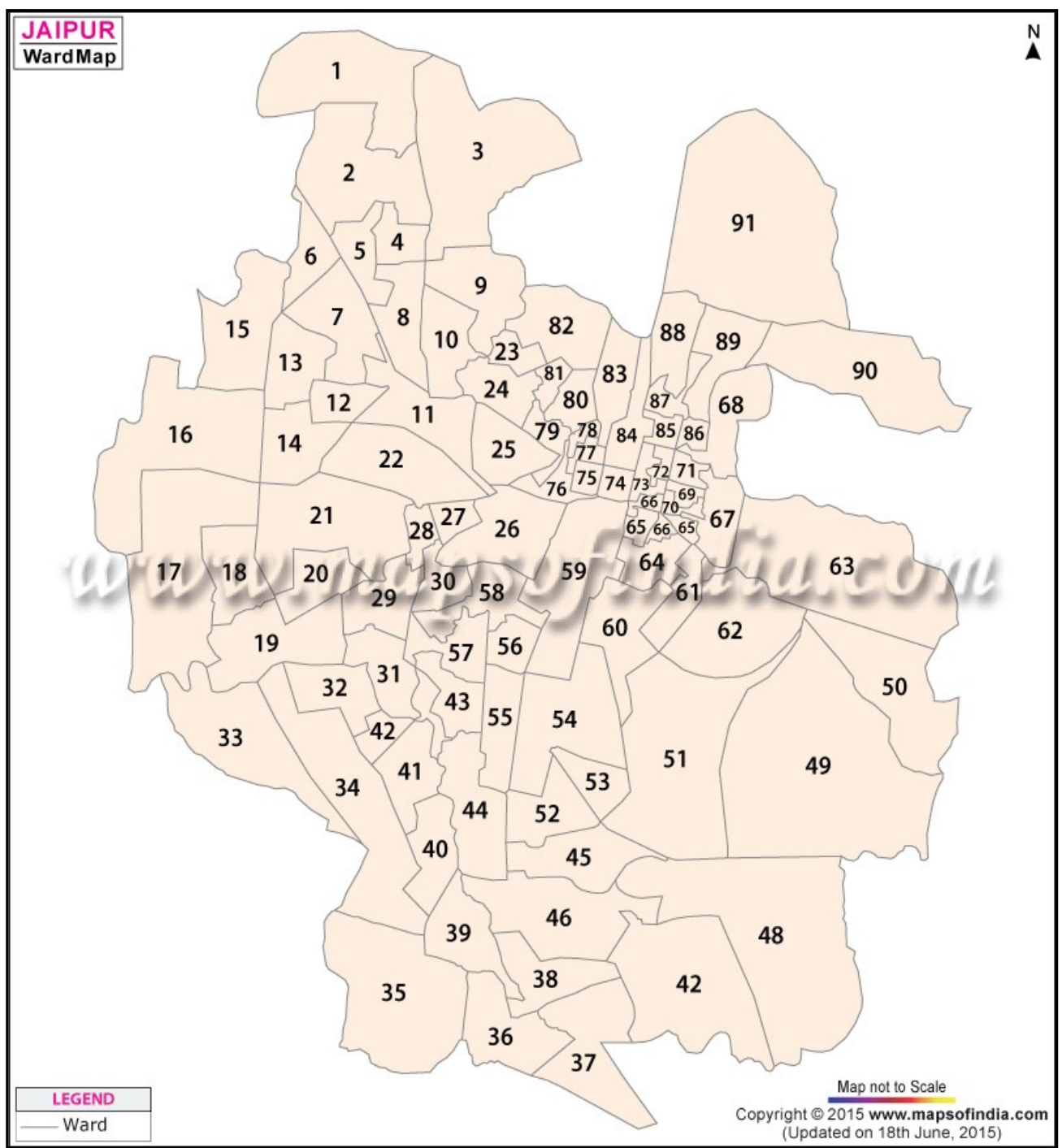

Ward Map of Jaipur 


\section{Household schedule}

Appendix 2

Now I would like to have some information about the people who usually live in your household $(H H)$. (Please add sheets and columns if more members are in the household).

\begin{tabular}{|c|c|c|c|c|c|}
\hline \multirow[t]{3}{*}{$\begin{array}{l}\text { LINE } \\
\text { NO } \\
001\end{array}$} & $\begin{array}{lr}\text { USUAL } & \text { RESI- } \\
\text { DENTS } & \text { OF } \\
\text { THE HH } & \end{array}$ & $\begin{array}{l}\text { RELATION- } \\
\text { SHIP WITH } \\
\text { THE HEAD OF } \\
\text { THE HH }\end{array}$ & SEX & AGE & $\begin{array}{l}\text { MARITAL } \\
\text { STATUS }\end{array}$ \\
\hline & Q 102 & Q002 & Q003 & Q004 & Q005 \\
\hline & $\begin{array}{l}\text { Please tell me } \\
\text { the names of } \\
\text { the person } \\
\text { who usually } \\
\text { lives in your } \\
\mathrm{HH} \text { starting } \\
\text { with the head } \\
\text { of the } \mathrm{HH}\end{array}$ & $\begin{array}{l}\text { What is the } \\
\text { relationship of } \\
\text { (NAME) to the } \\
\text { head of the } \\
\text { household? } \\
\text { (A) }\end{array}$ & $\begin{array}{l}\text { Is (NAME) } \\
\text { male or } \\
\text { female } \\
M=1 \\
\mathrm{~F}=2\end{array}$ & $\begin{array}{l}\text { How old is } \\
\text { (Name)? } \\
\text { (Completed } \\
\text { year) } \\
\text { (B) }\end{array}$ & $\begin{array}{l}\text { What is the current } \\
\text { marital status of } \\
\text { (name)? } \\
\mathrm{NM}=1 \\
\mathrm{CM}=2 \\
\mathrm{~S} / \mathrm{D}=3 \\
\mathrm{~W}=4 \\
\mathrm{MNG}=5 \\
\text { (C) }\end{array}$ \\
\hline \multicolumn{6}{|c|}{ 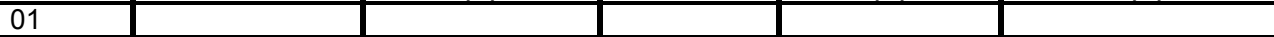 } \\
\hline \multicolumn{6}{|l|}{02} \\
\hline \multicolumn{6}{|l|}{03} \\
\hline \multicolumn{6}{|l|}{04} \\
\hline \multicolumn{6}{|l|}{05} \\
\hline \multicolumn{6}{|l|}{06} \\
\hline \multicolumn{6}{|l|}{07} \\
\hline \multicolumn{6}{|l|}{08} \\
\hline \multicolumn{6}{|l|}{09} \\
\hline \multicolumn{6}{|l|}{10} \\
\hline \multicolumn{6}{|l|}{11} \\
\hline \multicolumn{6}{|l|}{12} \\
\hline \multicolumn{6}{|l|}{13} \\
\hline \multicolumn{6}{|l|}{14} \\
\hline 15 & & & & & \\
\hline
\end{tabular}




\begin{tabular}{|c|c|c|c|c|c|c|}
\hline \multirow{4}{*}{$\begin{array}{l}\text { LINE } \\
\text { NO } \\
001\end{array}$} & \multicolumn{3}{|c|}{$\begin{array}{l}\text { EDUCATION } \\
\text { (If Age }>\text { / } 5 \text { years) }\end{array}$} & \multicolumn{3}{|c|}{ IF EVER ATTENED SCHOOL/ COLLEGE } \\
\hline & Q006 & Q007 & Q 008 & Q 009 & Q 010 & Q 011 \\
\hline & \multirow[b]{2}{*}{$\begin{array}{l}\text { Can } \\
\text { (Name) } \\
\text { read and } \\
\text { write? } \\
\text { Yes=1 } \\
\text { No=0 }\end{array}$} & \multirow[b]{2}{*}{$\begin{array}{l}\text { Has } \\
\text { (Name) } \\
\text { ever been } \\
\text { to school } \\
\text { Yes=1 } \\
\text { No=0 } \\
\text { IF YES } \\
\text { GO TO Q } \\
010\end{array}$} & \multirow[b]{2}{*}{$\begin{array}{l}\text { If never } \\
\text { attended } \\
\text { school } \\
\text { What is the } \\
\text { main reason } \\
\text { (Name) } \\
\text { went to } \\
\text { school? } \\
\text { (D) } \\
\text { (GO TO } \\
\text { NEXT PER- } \\
\text { SON) }\end{array}$} & \multirow[b]{2}{*}{$\begin{array}{l}\text { What is the } \\
\text { highest stand- } \\
\text { ard (Name) } \\
\text { has complet- } \\
\text { ed? } \\
\text { IF AGE IS } 18 \\
\text { YEARS OR } \\
\text { MORE GO TO } \\
\text { NEXT PER- } \\
\text { SON }\end{array}$} & \multicolumn{2}{|c|}{$\begin{array}{l}\text { IF AGE IS LESS THAN } 18 \\
\text { YEARS }\end{array}$} \\
\hline & & & & & $\begin{array}{l}\text { Is (Name) } \\
\text { still in school/ } \\
\text { college? } \\
\text { Yes=1 } \\
\text { No=2 } \\
\text { IF YES GO } \\
\text { TO NEXT } \\
\text { PERSON }\end{array}$ & $\begin{array}{l}\text { IF NOT IN } \\
\text { SCHOOL/ } \\
\text { COLLEGE } \\
\text { What is the } \\
\text { main rea- } \\
\text { son (Name) } \\
\text { not going to } \\
\text { school/ } \\
\text { college? } \\
\quad \text { (F) }\end{array}$ \\
\hline \multicolumn{7}{|l|}{01} \\
\hline \multicolumn{7}{|l|}{02} \\
\hline \multicolumn{7}{|l|}{03} \\
\hline \multicolumn{7}{|l|}{04} \\
\hline \multicolumn{7}{|l|}{05} \\
\hline \multicolumn{7}{|l|}{06} \\
\hline \multicolumn{7}{|l|}{07} \\
\hline \multicolumn{7}{|l|}{08} \\
\hline \multicolumn{7}{|l|}{09} \\
\hline \multicolumn{7}{|l|}{10} \\
\hline \multicolumn{7}{|l|}{11} \\
\hline \multicolumn{7}{|l|}{12} \\
\hline \multicolumn{7}{|l|}{13} \\
\hline \multicolumn{7}{|l|}{14} \\
\hline 15 & & & & & & \\
\hline
\end{tabular}




\begin{tabular}{|c|c|c|c|c|}
\hline \multirow{4}{*}{$\begin{array}{l}\text { LINE } \\
\text { NO } \\
001\end{array}$} & \multicolumn{3}{|c|}{ WORKING STATUS } & \multirow{2}{*}{$\begin{array}{l}\text { IDENTIFICATION OF ELGIBILE } \\
\text { ELDERLY } \\
\text { Q } 015\end{array}$} \\
\hline & \multirow{2}{*}{$\begin{array}{l}\text { Q } 012 \\
\text { What is } \\
\text { the current } \\
\text { working } \\
\text { status of } \\
\text { (Name)? }\end{array}$} & Q 013 & Q014 & \\
\hline & & \multicolumn{2}{|c|}{ IF (NAME) IS WORKING } & \multirow[b]{2}{*}{$\begin{array}{l}\text { Write (1) if Elderly Person above } \\
\text { age } 50 \text { years and (2) for others. } \\
\text { Also Circle Line No of Eligible } \\
\text { Respondents }\end{array}$} \\
\hline & $\begin{array}{l}\text { the current } \\
\text { working } \\
\text { status of } \\
\text { (Name)? } \\
\mathrm{CW}=1 \\
\mathrm{~S} / \mathrm{C} / \mathrm{P}=2 \\
\mathrm{R}=3 \\
\mathrm{HM}=4 \\
\mathrm{SJ}=5 \\
\mathrm{NW}=6\end{array}$ & $\begin{array}{l}\text { Is (Name) } \\
\text { in full time } \\
\text { or part } \\
\text { time em- } \\
\text { ployment } \\
\mathrm{FT}=1 \\
\mathrm{PT}=2\end{array}$ & $\begin{array}{l}\text { What is the nature } \\
\text { of employment? } \\
\text { GS }=1 \\
\text { Inst }=2 \\
N / T=3 \\
\mathrm{CS}=4 \\
\mathrm{PS}=5 \\
\mathrm{SE} / \mathrm{Bus}=6 \\
\mathrm{O}=96\end{array}$ & \\
\hline \multicolumn{5}{|r|}{ 1 } \\
\hline \multicolumn{5}{|l|}{02} \\
\hline \multicolumn{5}{|l|}{03} \\
\hline \multicolumn{5}{|l|}{04} \\
\hline \multicolumn{5}{|l|}{05} \\
\hline \multicolumn{5}{|l|}{06} \\
\hline \multicolumn{5}{|l|}{07} \\
\hline \multicolumn{5}{|l|}{08} \\
\hline \multicolumn{5}{|l|}{09} \\
\hline \multicolumn{5}{|l|}{10} \\
\hline \multicolumn{5}{|l|}{11} \\
\hline \multicolumn{5}{|l|}{12} \\
\hline \multicolumn{5}{|l|}{13} \\
\hline \multicolumn{5}{|l|}{14} \\
\hline 15 & & & & \\
\hline
\end{tabular}




\begin{tabular}{|c|c|c|c|}
\hline $\begin{array}{l}\text { A. CODES for Q103 } \\
\text { Relationship With the } \\
\text { Head of the Household } \\
\text { 1= Head } \\
2=\text { Wife or husband } \\
\text { 3= Son or daughter } \\
4=\text { Son-in-law or daugh- } \\
\text { ter-in-law } \\
\text { 5= Grandchild } \\
6=\text { Parent } \\
7=\text { Parent-in-law } \\
8=\text { Brother or sister } \\
9=\text { Brother-in-law or } \\
\text { sister-in-law } \\
\text { 10= Niece or nephew } \\
\text { 11= Other relative } \\
12=\text { Adopted/ Foster } \\
\text { Child/ Step Child } \\
\text { 13= Domestic servant } \\
\text { 14= Other not related } \\
98=\text { Don't know }\end{array}$ & $\begin{array}{l}\text { B. CODES for } \\
\text { Q105 } \\
\text { Age } \\
00=\text { Age less } \\
\text { than one year }\end{array}$ & $\begin{array}{l}\text { C. CODES for Q106 } \\
\text { Marital Status } \\
\text { 1= Never Married } \\
2=\text { Currently married } \\
3=\text { Separated / } \\
\text { Deserted/ Divorced } \\
4=\text { Widowed/ Widow- } \\
\text { er } \\
5=\text { Married but gauna } \\
\text { not performed }\end{array}$ & $\begin{array}{l}\text { D. CODES for } \\
\text { Q109 } \\
\text { Main Reasons: } \\
\text { 1= School too far } \\
\text { away } \\
\text { 2= Transport not } \\
\text { available } \\
\text { 3= Education not } \\
\text { considered } \\
\text { necessary } \\
4=\text { Required for } \\
\text { household } \\
5=\text { Required for } \\
\text { work on farm/ family } \\
6=\text { Required to work } \\
\text { outside to earn } \\
7=\text { Expensive } \\
\text { 8= No proper } \\
\text { school facilities for } \\
\text { girls } \\
9=\text { Required to care } \\
\text { for younger siblings } \\
\text { 10= Not interested } \\
\text { in studies } \\
96=\text { Any other } \\
\text { reason (Specify) } \\
98=\text { Don't know }\end{array}$ \\
\hline
\end{tabular}




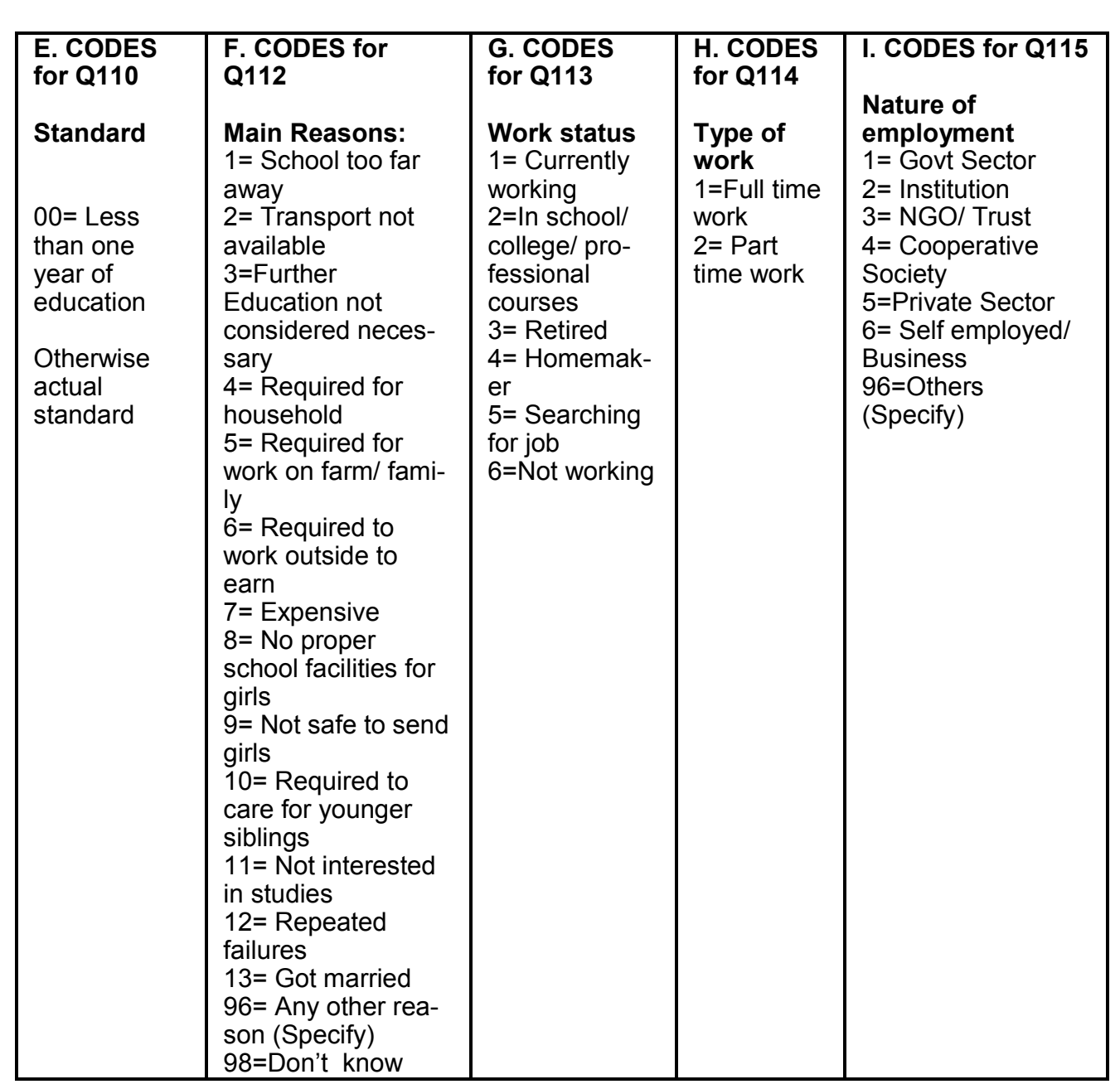




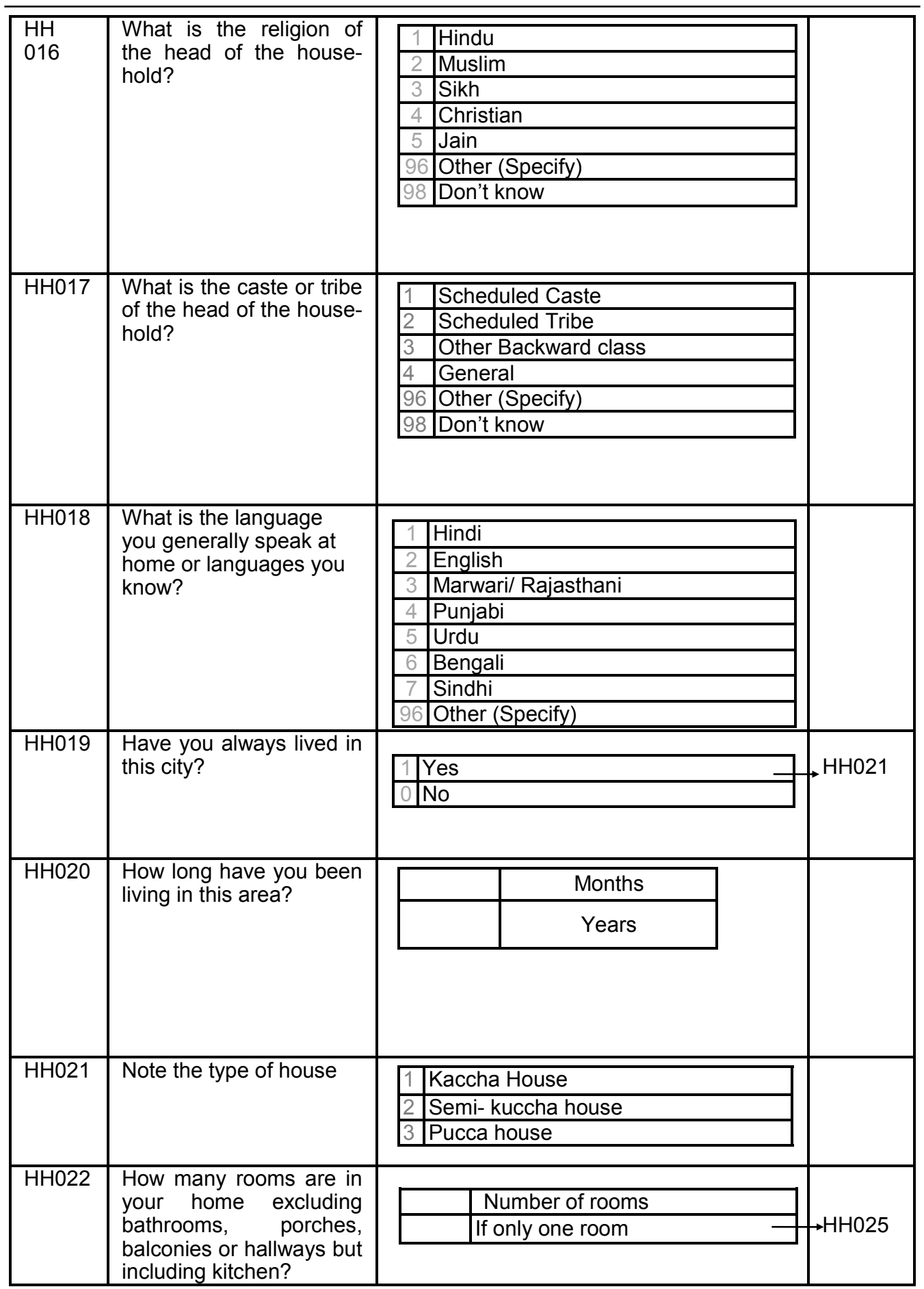




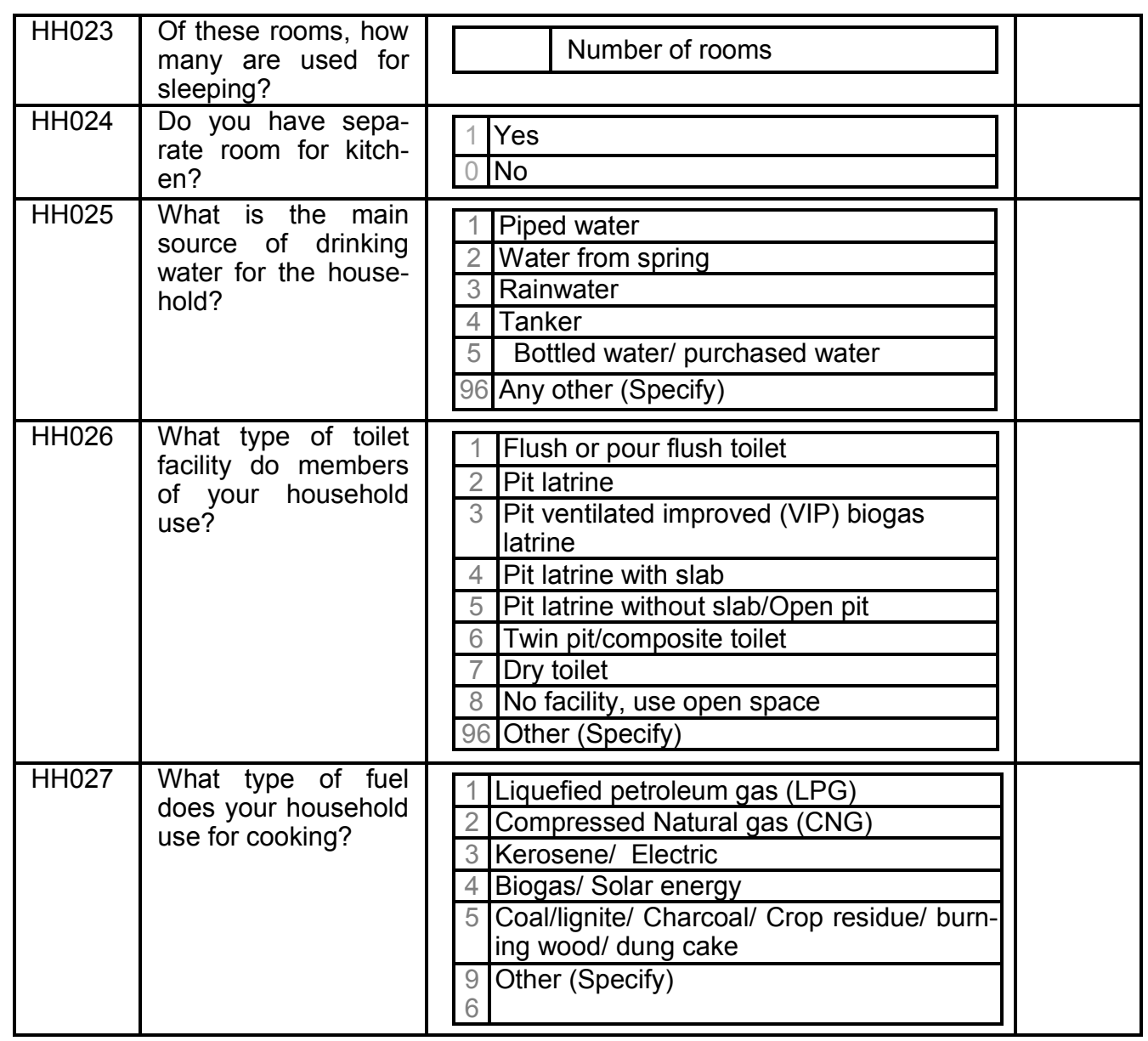




\begin{tabular}{|c|c|c|c|c|}
\hline $\mathrm{HH} 028$ & $\begin{array}{l}\text { Does your household } \\
\text { have the following: }\end{array}$ & $\begin{array}{l}\text { Assets } \\
\text { Refrigerator } \\
\text { Washing Machine } \\
\text { Sewing Machine } \\
\text { Television } \\
\text { Mixer } \\
\text { Pressure Cooker } \\
\text { Dishwasher } \\
\text { Telephone } \\
\text { Mobile Phone } \\
\text { Radio/Transistor/ Stereo } \\
\text { System/ CD Player } \\
\text { Computer } \\
\text { Air Conditioner } \\
\text { Cot or bed/ Mattress } \\
\text { Electric Fan } \\
\text { Cooler } \\
\text { Car/ any four wheeler } \\
\text { Motorcycles/ Scooter/ } \\
\text { Mopeds } \\
\text { Bicycles }\end{array}$ & $\begin{array}{c}\text { Yes } \\
1 \\
1 \\
1 \\
1 \\
1 \\
1 \\
1 \\
1 \\
1 \\
1 \\
1 \\
1 \\
1 \\
1 \\
1 \\
1 \\
1\end{array}$ & $\begin{array}{c}\text { No } \\
0 \\
0 \\
0 \\
0 \\
0 \\
0 \\
0 \\
0 \\
0 \\
0\end{array}$ \\
\hline
\end{tabular}

Thank you for your cooperation and giving your precious time. 
Individual questionnaire

\begin{tabular}{|c|c|c|c|c|}
\hline Variables & Questions and Filters & \multicolumn{2}{|c|}{ Coding Categories } & Skip/Go to \\
\hline D001 & $\begin{array}{l}\text { Note down the sex of the } \\
\text { respondent }\end{array}$ & \multicolumn{2}{|c|}{\begin{tabular}{|l|l|}
1 & Male \\
2 & Female \\
\end{tabular}} & \\
\hline D002 & $\begin{array}{l}\text { What is your current } \\
\text { marital status? }\end{array}$ & \multicolumn{2}{|c|}{\begin{tabular}{|l|l|}
1 & Never Married \\
2 & Married \\
3 & Separated/ Deserted \\
4 & Divorced \\
5 & Widowed \\
\end{tabular}} & \\
\hline D003 & $\begin{array}{l}\text { Tell me the living ar- } \\
\text { rangement of your house }\end{array}$ & \multicolumn{2}{|c|}{\begin{tabular}{|l|l|}
1 & Living Alone \\
2 & Living with spouse only \\
3 & $\begin{array}{l}\text { Living with spouse and chil- } \\
\text { dren or others }\end{array}$ \\
4 & $\begin{array}{l}\text { Living without spouse but } \\
\text { with children or others }\end{array}$ \\
5 & Living with others \\
\end{tabular}} & $\rightarrow D 005 A$ \\
\hline D004 & $\begin{array}{l}\text { Can you please tell me } \\
\text { why are you staying } \\
\text { alone? }\end{array}$ & & & \\
\hline \multirow[t]{2}{*}{ D005 } & \multirow[t]{2}{*}{$\begin{array}{l}\text { What is your date of } \\
\text { birth? } \\
\text { In which year and month } \\
\text { were you born? }\end{array}$} & & \begin{tabular}{|c|} 
Don't know \\
98 \\
98 \\
98 \\
\end{tabular} & \multirow[t]{2}{*}{ D007 } \\
\hline & & $\begin{array}{l}\mathrm{D} 005 \mathrm{~A} \\
\mathrm{D} 005 \mathrm{~B} \\
\mathrm{D} 005 \mathrm{C}\end{array}$ & \begin{tabular}{|c|} 
Day of birth \\
Month of birth \\
Year of birth \\
\end{tabular} & \\
\hline D006 & $\begin{array}{l}\text { How old were you on } \\
\text { your last birthday? } \\
\text { Compare and correct } \\
\text { D005 and D006 if incon- } \\
\text { sistent }\end{array}$ & & & \\
\hline D007 & Can you read and write? & \begin{tabular}{|l|l|}
1 & Able t \\
2 & Able t \\
3 & Able t \\
4 & Cann \\
\end{tabular} & $\begin{array}{l}\text { read only } \\
\text { write only } \\
\text { read and write } \\
\text { read or write } \\
\end{array}$ & \\
\hline
\end{tabular}




\begin{tabular}{|c|c|c|c|}
\hline D008 & $\begin{array}{l}\text { What is the highest level } \\
\text { of education that you } \\
\text { have completed? }\end{array}$ & \begin{tabular}{|l|l|}
0 & No education \\
1 & Primary \\
2 & Secondary \\
3 & Higher secondary \\
4 & Diploma/ Certificate course \\
5 & Graduation \\
6 & Post graduation or above \\
\end{tabular} & \\
\hline D008A & Years of schooling & 0 to 40 years & \\
\hline D009 & $\begin{array}{l}\text { What is your current } \\
\text { working status? }\end{array}$ & \begin{tabular}{|l|l|}
1 & Currently working \\
2 & $\begin{array}{l}\text { Re-employed after retire- } \\
\text { ment }\end{array}$ \\
3 & Retired \\
4 & Home-maker \\
5 & Unable to work \\
6 & Not working \\
\end{tabular} & $\longrightarrow \mathrm{D} 016$ \\
\hline D010 & $\begin{array}{l}\text { Where are/were you } \\
\text { working before retire- } \\
\text { ment? }\end{array}$ & \begin{tabular}{|l|l|}
1 & Government sector \\
2 & Institution \\
3 & $\begin{array}{l}\text { Cooperative society/ cooper- } \\
\text { ation/ NGO/ Trust }\end{array}$ \\
4 & Private sector \\
5 & Business \\
6 & Self employed/ \\
96 & Others \\
\end{tabular} & \\
\hline
\end{tabular}




\section{Health care utilization}

\begin{tabular}{|c|c|c|}
\hline HS001 & $\begin{array}{l}\text { How do you rate your } \\
\text { current health status? }\end{array}$ & \begin{tabular}{|l|l|}
1 & Excellent \\
2 & Fairly Good \\
3 & Normal \\
4 & Poor (Sick) \\
5 & Bad (Bed Ridden) \\
98 & Don't know/ Can't say \\
99 & Refuse to answer \\
\end{tabular} \\
\hline HS002 & $\begin{array}{l}\text { What is your current } \\
\text { health status as com- } \\
\text { pared to last month? }\end{array}$ & \begin{tabular}{|l|l|}
1 & Improved \\
2 & Same/ no change \\
3 & Worsened \\
98 & Don't know/ Can't say \\
99 & Refuse to answer \\
\end{tabular} \\
\hline HS003 & $\begin{array}{l}\text { What is your current } \\
\text { health status as com- } \\
\text { pared to last one year? }\end{array}$ & \begin{tabular}{|l|l|}
1 & Improved \\
2 & Same/ no change \\
3 & Worsened \\
98 & Don't know/ Can't say \\
99 & Refuse to answer \\
\end{tabular} \\
\hline HSO04 & $\begin{array}{l}\text { Which health facility do } \\
\text { you prefer for health } \\
\text { care and treatment } \\
\text { seeking in case of any } \\
\text { minor illness? }\end{array}$ & \begin{tabular}{|l|l|}
1 & Government clinics \\
2 & Community/ charity centers \\
3 & Private Practioners \\
4 & $\begin{array}{l}\text { AYUSH (Ayurvedic, Siddha, Homeopa- } \\
\text { thy, Unani) }\end{array}$ \\
5 & Pharmacy/ Drug store \\
6 & Home remedies \\
7 & No specific preference \\
99 & Refuse to answer \\
\end{tabular} \\
\hline HS005 & $\begin{array}{l}\text { Which health facility do } \\
\text { you prefer for health } \\
\text { care and treatment } \\
\text { seeking in case of any } \\
\text { major illness? }\end{array}$ & \begin{tabular}{|l|l|}
1 & Government hospitals \\
2 & Community centers \\
3 & NGO/Charity hospital \\
4 & Private hospitals \\
5 & No specific preference \\
99 & Refuse to answer \\
\end{tabular} \\
\hline
\end{tabular}




\begin{tabular}{|c|c|c|c|c|c|c|}
\hline \multirow[t]{11}{*}{ HS006 } & \multirow{11}{*}{$\begin{array}{l}\text { What are the factors } \\
\text { that govern your pref- } \\
\text { erence? }\end{array}$} & \multicolumn{4}{|l|}{\begin{tabular}{|l|l|}
1 & Affordable facilities \\
\end{tabular}} & \\
\hline & & \multicolumn{4}{|l|}{\begin{tabular}{|l|l|}
2 & Better facilities \\
\end{tabular}} & \\
\hline & & \multicolumn{4}{|c|}{\begin{tabular}{|l|l|}
3 & Less corruption \\
\end{tabular}} & \\
\hline & & \multicolumn{4}{|c|}{\begin{tabular}{|l|l|}
4 & Best doctors wherever available \\
\end{tabular}} & \\
\hline & & \multicolumn{4}{|c|}{\begin{tabular}{l|l}
5 & CGHS authorized hospitals
\end{tabular}} & \\
\hline & & \multicolumn{4}{|c|}{\begin{tabular}{|l|l|}
6 & Reimbursement facilities \\
\end{tabular}} & \\
\hline & & \multicolumn{4}{|c|}{\begin{tabular}{|l|l|}
7 & Better look after and interaction \\
\end{tabular}} & \\
\hline & & \multicolumn{4}{|c|}{\begin{tabular}{|l|l|}
8 & Availability of facilities \\
\end{tabular}} & \\
\hline & & \multicolumn{4}{|c|}{\begin{tabular}{|l|l}
9 & Service motive \\
\end{tabular}} & \\
\hline & & \multicolumn{4}{|c|}{\begin{tabular}{|l|l|}
10 & Familiar doctor or known people \\
\end{tabular}} & \\
\hline & & \multicolumn{4}{|c|}{\begin{tabular}{|l|l|}
96 & Other \\
\end{tabular}} & \\
\hline \multirow[t]{4}{*}{ HS007 } & \multirow{4}{*}{$\begin{array}{l}\text { Are you going for } \\
\text { health check up? }\end{array}$} & \multicolumn{4}{|l|}{\begin{tabular}{|l|l|}
1 & Yes, regular \\
\end{tabular}} & \\
\hline & & \multicolumn{4}{|l|}{\begin{tabular}{|l|l|}
2 & Often \\
\end{tabular}} & \\
\hline & & \multicolumn{4}{|l|}{\begin{tabular}{|l|l}
3 & Rarely/occasionally \\
\end{tabular}} & \\
\hline & & \multicolumn{4}{|l|}{\begin{tabular}{|l|l|}
0 & No \\
\end{tabular}} & \\
\hline \multirow[t]{10}{*}{ HS008 } & \multirow{10}{*}{$\begin{array}{l}\text { Have you been diag- } \\
\text { nosed by any health } \\
\text { professional from any } \\
\text { of the following ail- } \\
\text { ment in last } 30 \text { days: }\end{array}$} & \multicolumn{2}{|l|}{ Disease } & Yes & No & \\
\hline & & \multicolumn{2}{|l|}{ a Cough } & 1 & 0 & \\
\hline & & \multicolumn{2}{|l|}{ b Fatigue } & 1 & 0 & \\
\hline & & \multicolumn{2}{|c|}{ c Hearing problems } & 1 & 0 & \\
\hline & & \multicolumn{2}{|c|}{$\begin{array}{l}\mathrm{d} \text { Problem in vision (cataract } \\
\text { etc) }\end{array}$} & 1 & 0 & \\
\hline & & e Dental/tooth problem & & 1 & 0 & \\
\hline & & f Skin problem & & 1 & 0 & \\
\hline & & g Trouble breathing & & 1 & 0 & \\
\hline & & h Memory loss & & 1 & 0 & \\
\hline & & i Swollen ankles or feet & & 1 & 0 & \\
\hline HS009 & Has any of the health & Disease & $\overline{\mathbf{Y}}$ & $\mathbf{N}$ & & \\
\hline & professional diag- & a Hypertension & 1 & 0 & & \\
\hline & & b Diabetes & 1 & 0 & & \\
\hline & & c Angina & 1 & 0 & & \\
\hline & & d Arthritis & 1 & 0 & & \\
\hline & & $\begin{array}{l}\text { e Lung disorder (eg. } \\
\text { asthma) }\end{array}$ & 1 & 0 & & \\
\hline & & $\begin{array}{c}\text { f } \begin{array}{c}\text { Heart disease } \\
\text { cholesterol) }\end{array} \\
\text { ch. }\end{array}$ & 1 & 0 & & \\
\hline & & g Thyroid & 1 & 0 & & \\
\hline & & h Spondylitis & 1 & 0 & & \\
\hline & & $\begin{array}{l}\text { i Genital ulcers /Painful } \\
\text { urination }\end{array}$ & 1 & 0 & & HS012 \\
\hline & & j Slip Disc & 1 & 0 & & \\
\hline & & k Cervical & 1 & 0 & & \\
\hline & & I Polio/ Paralysis & 1 & 0 & & \\
\hline & & m Any other (Specify) & 1 & 0 & & \\
\hline
\end{tabular}




\begin{tabular}{|c|c|c|c|c|}
\hline HS010 & $\begin{array}{l}\text { Are you taking any } \\
\text { treatment for your } \\
\text { disease? }\end{array}$ & \begin{tabular}{|l|}
1 \\
0 \\
\end{tabular} & \begin{tabular}{|l|} 
Yes, on regular basis \\
No
\end{tabular} & $\stackrel{\mathrm{HSO}}{\longrightarrow} 12$ \\
\hline HS011 & $\begin{array}{l}\text { Why are you not } \\
\text { seeking treatment or } \\
\text { go to the hospital? }\end{array}$ & \begin{tabular}{|l|}
1 \\
2 \\
3 \\
4 \\
5 \\
6 \\
96 \\
99 \\
\end{tabular} & \begin{tabular}{|l|} 
Monetary issues \\
Illness was not serious \\
$\begin{array}{l}\text { Disease can't be cured so no use of } \\
\text { treatment }\end{array}$ \\
No willingness to go \\
Have faith on almighty \\
Have medicines at home/ self treatment \\
Any other reason (specify) \\
Refuse to answer \\
\end{tabular} & \\
\hline & $\begin{array}{l}\text { Now I would like to a } \\
\text { facility (in the past th } \\
\text { HS021) }\end{array}$ & & $\begin{array}{l}\text { estions about your most recent visit to } \\
\text { ays), pharmacist or healthcare provide }\end{array}$ & $\begin{array}{l}\text { medical } \\
\text { HS012 to }\end{array}$ \\
\hline HS012 & $\begin{array}{l}\text { Within the past thirty } \\
\text { days have you visited } \\
\text { any medical facilities, } \\
\text { pharmacist or } \\
\text { healthcare provider? }\end{array}$ & \begin{tabular}{|l|}
1 \\
0 \\
\end{tabular} & \begin{tabular}{|l|} 
Yes \\
No \\
\end{tabular} & $\overrightarrow{\mathrm{HSO}} 18 \mathrm{~A}$ \\
\hline HS013 & $\begin{array}{l}\text { Which health care } \\
\text { facility did you visit } \\
\text { the last time you } \\
\text { went? }\end{array}$ & \begin{tabular}{|l|}
1 \\
2 \\
3 \\
4 \\
5 \\
6 \\
\end{tabular} & \begin{tabular}{|l} 
Government hospitals/ clinics \\
Community centers \\
NGO/Charity hospital \\
Private hospitals/clinics \\
$\begin{array}{l}\text { AYUSH (Ayurvedic, Siddha, Homeopa- } \\
\text { thy, Unani) }\end{array}$ \\
Pharmacy/ Drug store
\end{tabular} & \\
\hline HS014 & $\begin{array}{l}\text { Who accompanied } \\
\text { you? }\end{array}$ & \begin{tabular}{|l|}
1 \\
2 \\
3 \\
4 \\
5 \\
\end{tabular} & \begin{tabular}{|l|} 
Family member \\
Friend \\
Relative \\
Someone else \\
No one \\
\end{tabular} & \\
\hline HS015 & $\begin{array}{l}\text { Did your provider } \\
\text { prescribe medicines } \\
\text { at the visit? }\end{array}$ & \begin{tabular}{|l|}
1 \\
0 \\
\end{tabular} & \begin{tabular}{|l|} 
Yes \\
No \\
\end{tabular} & $\overrightarrow{\mathrm{HS}} 018 \mathrm{~A}$ \\
\hline HS016 & $\begin{array}{l}\text { Did you obtain the } \\
\text { medicine? }\end{array}$ & \begin{tabular}{|l|}
1 \\
0 \\
\end{tabular} & \begin{tabular}{|l|} 
Yes \\
No \\
\end{tabular} & $\longrightarrow$ \\
\hline
\end{tabular}




\begin{tabular}{|c|c|c|}
\hline HS017 & $\begin{array}{l}\text { Why you did not ob- } \\
\text { tain the medicine? }\end{array}$ & \begin{tabular}{|l|l|}
1 & Did not have money \\
2 & Unable to find medicine \\
3 & Medicine was at home \\
4 & Did not think medicine was effective \\
96 & Any Other (specify) \\
\end{tabular} \\
\hline HS018 & $\begin{array}{l}\text { Overall, in general } \\
\text { how are you largely } \\
\text { meeting your medical } \\
\text { expenditure? }\end{array}$ & \begin{tabular}{|l|l|} 
A & By own savings YES 1 NO 0 \\
B & By pension/ income \\
C & Borrowing \\
D & Met by commercial insurance \\
E & Met by family insurance \\
F & $\begin{array}{l}\text { Availing government facilities or employ- } \\
\text { er facilities }\end{array}$ \\
G & Dependant on family \\
$H$ & Any other \\
\end{tabular} \\
\hline HS019 & $\begin{array}{l}\text { Overall, how is the } \\
\text { quality of medical } \\
\text { care that you re- } \\
\text { ceive? }\end{array}$ & \begin{tabular}{|l|l|}
1 & Excellent \\
2 & Very good \\
3 & Average \\
4 & Poor \\
5 & Pathetic/ very poor \\
\end{tabular} \\
\hline
\end{tabular}

Thank you for your cooperation and giving your precious time. 
Kshipra JAIN, Perianaygam AROKIASAMY

Demographic and economic information of sample population

Appendix 4

(Urban Jaipur, 2013)

\begin{tabular}{|c|c|c|c|c|c|}
\hline & Percent & $\mathbf{N}$ & & Percent & $\mathbf{N}$ \\
\hline Age & & & Insurance coverage & & \\
\hline $50-54$ & 31.83 & 127 & CGHS & 18.73 & 47 \\
\hline $55-59$ & 18.05 & 72 & State Government & 23.51 & 59 \\
\hline $60-64$ & 16.04 & 64 & Medi-claim Policy & 22.31 & 56 \\
\hline $65-69$ & 13.28 & 53 & $\begin{array}{l}\text { Employer } \\
\text { Reimbursement }\end{array}$ & 7.57 & 19 \\
\hline $70-75$ & 11.03 & 44 & Private Health Insurance & 3.98 & 10 \\
\hline 76 and above & 10.00 & 40 & Private Life Insurance & 14.34 & 36 \\
\hline Gender & & & Govt life insurance & 21.91 & 55 \\
\hline Male & 61.75 & 247 & Family Insurance & 3.98 & 10 \\
\hline Female & 38.25 & 153 & No cover & 37.25 & 149 \\
\hline \multicolumn{6}{|l|}{ Education level } \\
\hline Male & & & & Mean & \\
\hline No education & 4.05 & 10 & $\begin{array}{l}\text { Average Household } \\
\text { size }\end{array}$ & 4.75 & \\
\hline Up to primary & 6.88 & 17 & $\begin{array}{l}\text { Average Household } \\
\text { income }\end{array}$ & 52689.57 & \\
\hline Up to secondary & 3.24 & 8 & $\begin{array}{l}\text { Average Household } \\
\text { expenditure }\end{array}$ & 21913.12 & \\
\hline $\begin{array}{l}\text { Up to higher } \\
\text { secondary }\end{array}$ & 7.29 & 18 & & & \\
\hline Graduation & 44.94 & 111 & $\begin{array}{l}\text { Mean age (Standard } \\
\text { deviation) }\end{array}$ & $\begin{array}{c}61.16 \\
( \pm 9.2370)\end{array}$ & \\
\hline $\begin{array}{l}\text { Post graduation or } \\
\text { above }\end{array}$ & 33.60 & 83 & & & \\
\hline \multicolumn{6}{|l|}{ Female } \\
\hline No education & 29.41 & 45 & & & \\
\hline Up to primary & 16.34 & 25 & & & \\
\hline Up to secondary & 15.03 & 23 & & & \\
\hline $\begin{array}{l}\text { Up to higher } \\
\text { secondary }\end{array}$ & 7.84 & 12 & & & \\
\hline Graduation & 17.65 & 27 & & & \\
\hline $\begin{array}{l}\text { Post graduation or } \\
\text { above }\end{array}$ & 13.73 & 21 & & & \\
\hline \multicolumn{6}{|l|}{ Social group } \\
\hline SC/ST & 13.50 & 54 & & & \\
\hline $\mathrm{OBC}$ & 17.50 & 70 & & & \\
\hline General & 69.00 & 276 & & & \\
\hline \multicolumn{6}{|l|}{ Religion } \\
\hline Hindu & 68.25 & 273 & & & \\
\hline Muslim & 11.50 & 46 & & & \\
\hline Jain & 14.50 & 58 & & & \\
\hline Others & 5.75 & 23 & & & \\
\hline Total & 100 & 400 & & & \\
\hline
\end{tabular}

